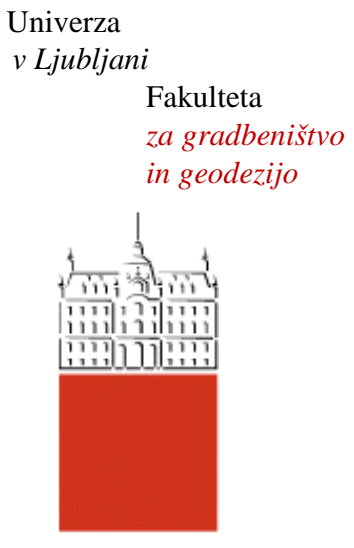

Jamova cesta 2

1000 Ljubljana, Slovenija

http://www3.fgg.uni-lj.si/

\section{DRUGG - Digitalni repozitorij UL FGG http://drugg.fgg.uni-lj.si/}

Ta članek je avtorjeva zadnja recenzirana različica, kot je bila sprejeta po opravljeni recenziji.

Prosimo, da se pri navajanju sklicujte na bibliografske podatke, kot je navedeno:

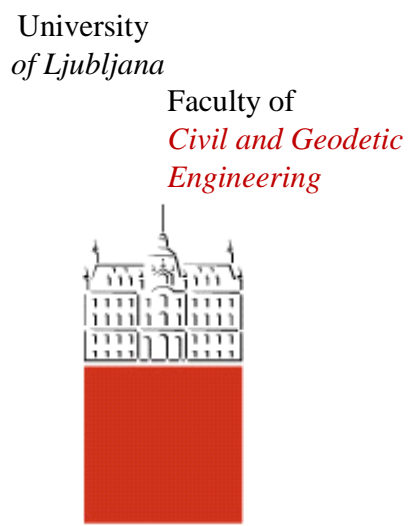

Jamova cesta 2

SI - 1000 Ljubljana, Slovenia

http://www3.fgg.uni-lj.si/en/

DRUGG - The Digital Repository http://drugg.fgg.uni-lj.si/

This version of the article is author's manuscript as accepted for publishing after the review process.

When citing, please refer to the publisher's bibliographic information as follows:

Šraj, M., Brilly, M., Mikoš., M. 2008. Rainfall interception by two deciduous Mediterranean forests of contrasting stature in Slovenia. Agricultural and forest meteorology 148, 1: 121134.

http://www.sciencedirect.com/science/article/pii/S0168192307002547 


\title{
Rainfall interception by two deciduous Mediterranean forests of contrasting stature in Slovenia
}

\author{
Mojca Šraj*, Mitja Brilly, Matjaž Mikoš \\ University of Ljubljana, Faculty of Civil and Geodetic Engineering, Jamova 2, SI-1000 Ljubljana, \\ Slovenia
}

\section{ARTICLE INFO \\ Article history: \\ Received 28 June 2006 \\ Accepted 26 Sept 2007}

Keywords:

Rainfall interception

Throughfall

Stemflow

Leaf area index

Gash model

Wind

\begin{abstract}
Measurements of precipitation above the canopy, throughfall and stemflow were made on the south and north-facing slopes of a deciduous forest on the experimental watershed of the Dragonja river in SW Slovenia. The Dragonja watershed was chosen for the experimental watershed, being of interest because of intensive natural reforestation in the last decades that caused a decrease in minimum and maximum flows. At the same time no noticeable precipitation and temperature changes were observed. Two forest plots were selected. One is located on the north-facing slope (1419 m2) and the other on the south-facing slope (615 m2). Analyses and modelling were made for a one-year period from October 2000 to September 2001. The leaf area index (LAI) was estimated by three methods, one direct and two indirect ones. The obtained values of LAI with the direct method were 6.6 and 6.9 for the south and north slopes, respectively. Measurements and regression analyses gave the mean annual throughfall value ( \pm standard error) on the south plot $67.1( \pm 9.6) \%$ of gross precipitation, and 71.5 ( \pm 11.6$) \%$ on the north plot. The average stemflow values were $4.5( \pm 0.8) \%$ of gross precipitation in the south plot and $2.9( \pm 0.6) \%$ in the north plot. The average annual interception losses amount to 28.4 ( \pm 4.1 ) and 25.4 ( \pm 4.0) \% for the south and north slopes, respectively. In the study a significant influence of the south-east wind was proven. With regression analyses and the classification decision tree model it was established that at the events with more than $7 \mathrm{~mm}$ of precipitation and south-east wind with a speed higher than $4 \mathrm{~m} / \mathrm{s}$ an unusually low amount of throughfall occurred and thus high interception losses. The analytical Gash model of rainfall interception (Gash, 1979; Gash et al., 1995) was successfully applied. The results of the modelling corresponded well to the observed values and were within the limits of the standard error of the observed values.
\end{abstract}

\section{Introduction}

Undoubtedly, forests exert a major influence on water regime. However, since the second half of the $20^{\text {th }}$ century, worldwide studies have shown that forest harvesting causes an increase in minimum and maximum runoff (Bosch and Hewlett, 1982; Swank et al., 1988; Bruijnzeel, 2000; Jones, 2000), on the other hand, an increase in regrowth results in a reduction of surface water runoff (Law, 1956; Calder, 1998; Waterloo et al., 1999; Putuhena and Cordery, 2000). This is true for the Dragonja watershed in SW Slovenia as well, where the gradual natural reforestation of the area in the last decades of the $20^{\text {th }}$ century resulted in a decrease in the minimum, median and maximum discharge of the Dragonja river. The mean annual discharge in the period 1961-1995 reduced by $35 \%$ (Globevnik, 2001). The number of days with

\footnotetext{
* Corresponding author: Tel.: +386 142540 52, fax: +386 125198 97, E-mail: mojca.sraj@fgg.uni-lj.si 0168-1923/\$ - see front matter (C) 2007 Elsevier B.V. All rights reserved. doi:10.1016/j.agrformet.2007.09.007
} 
extremely low discharge increased by $30 \%$ and the frequency of high waters decreased by $60 \%$ (Globevnik, 2001). The most significant decrease has been identified in the mean monthly minimum discharge, estimated at $4.4 \%$ per year with regard to the average monthly minimum discharge. There is a trend of reducing water runoff from the watershed. The runoff coefficients in an average year decreased by $10 \%$, in a wet year by $10-15 \%$, and in a dry year by 20-30\%, respectively (Globevnik, 2001). Owing to a smaller degree of changes of meteorological components (precipitation, temperature, solar radiation, and potential evapotranspiration), as opposed to the trends related to runoff (Globevnik, 2001), it can be assumed that the reduction in runoff in the Dragonja watershed can be attributed to a great change in land use in a very short period.

Interception loss is a major component in the water balance of forested areas as demonstrated by numerous studies (e.g., Horton, 1919; Law, 1956; Rutter, 1967; Zinke, 1967; Gash and Stewart, 1977; Stewart, 1977; Gash et al., 1980; Bruijnzeel and Wiersum, 1987; Schellekens et al., 1999; Putuhena and Cordery, 2000). The objective of the study was (1) to evaluate the quantity of the intercepted precipitation throughfall and stemflow, (2) to explore the influence of canopy structure and aspect on interception and throughfall, (3) to explore the influence of wind speed and direction, and therefore air mass properties on interception and throughfall, and (4) to evaluate Gash's model for the deciduous forest on the Dragonja watershed through measurements of single elements of the forest hydrologic cycle and determination of vegetation parameters. Therefore the water balance equation and Gash's model were used. Because of the seasonal changes in the canopy structure of the deciduous forest all parameters for the model were estimated separately for four vegetation periods to find out the influence of canopy structure on interception. Furthermore, we made a comparison of all the parametres and the intercepted precipitation in two forests on the south and north facing slopes, only about $400 \mathrm{~m}$ apart. That is one of the contributions of the study. Namely, the forests on the south and north slopes of the watershed differ considerably in terms of structure, density and tree height as well as in composition, thus they need to be dealt with separately despite their close proximity. Additionally, interception losses for different wind directions and speeds were investigated.

\section{The study area}

\subsection{General}

The Dragonja watershed is located in the southwestern part of Slovenia near the Adriatic coast (Fig. 1). The region is part of the Istrian Peninsula. The watershed is a hilly region, between 150 and $450 \mathrm{~m}$ above sea level and with an area of $90.5 \mathrm{~km}^{2}$. The Dragonja river is a border river between Slovenia and Croatia. It flows into the Sečovlje salt pans (nature park, a Ramsar locality) before reaching the Adriatic Sea. The watershed is divided into five subwatersheds on the fourth level of the watershed coding system of Slovenia (Šraj, 2001). 


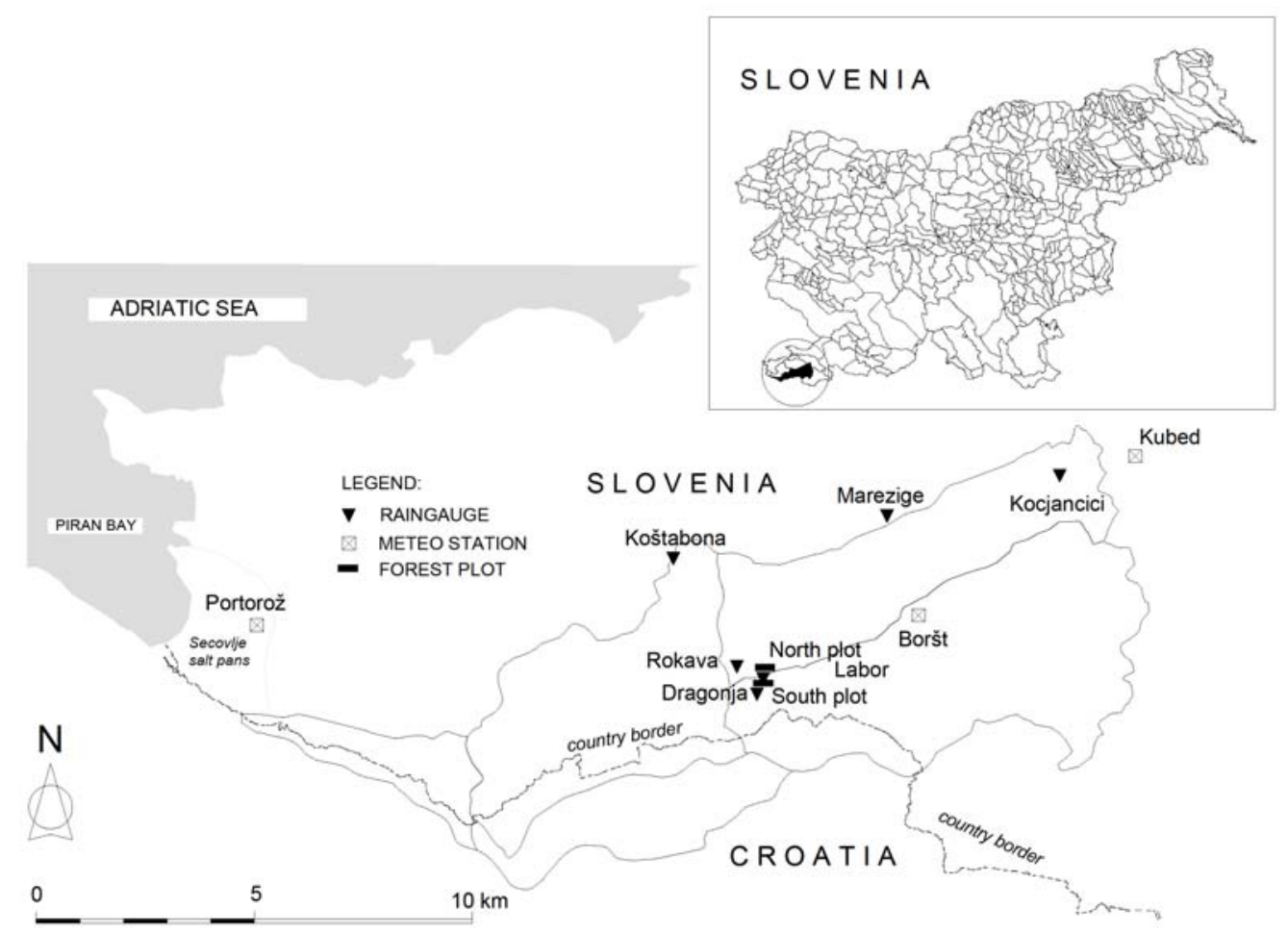

Fig. 1. Location of the study site in the Dragonja watershed, southwestern Slovenia and measurement stations.

The Dragonja river with its tributaries has cut into Eocene flysch between the Trieste and Buje Karst. The prevalent soil type is carbonate calcisols (Brilly and Globevnik, 2003; Keestra et al., 2005).

According to today's standards, the Dragonja watershed has a low population density. Characteristically, the area was mainly inhabited in the wide, hilly ridge tops, but the narrow tributary valleys and the Dragonja valley remained sparsely populated. Before 1955, land use in the watershed area was extensive agriculture but in the 1960's and 1970's the region depopulated and this led to the abandonment of extensive agricultural land use. Combined with the anti-erosion vegetation stabilisation works, this increased natural reforestation of land. In the Dragonja watershed an increase in regrowth from an average of $25 \%$ (in 1953) to more than $60 \%$ (today) was observed (Globevnik et al., 2004).

The monthly precipitation distribution can be described as sub-Mediterranean but there is no strong seasonality in rainfall distribution (Petkovšek and Mikoš, 2004), i.e. dry summer months and wet winter months. Rather, all months are nearly equally wet except for autumn with $30 \%$ of the annual precipitation. The total annual precipitation increases with the distance from the sea, ranging from $1000 \mathrm{~mm}$ (coast line) to $1300 \mathrm{~mm}$ (the upper watershed area). Snow is extremely rare and moderate. The mean annual temperatures by the coast are around $14^{0} \mathrm{C}$, and approx. $2-3^{0} \mathrm{C}$ lower further inland. The most common wind is a north-east wind called the "burja", which occurs in more than one-third of the year. The south-easterly "jugo" and southerly "jug" are the others most frequent winds (Ogrin, 1995).

The Dragonja watershed has been classified as having deciduous sub-Mediterranean vegetation. The vegetation mostly consists of pubescent oak, Karst ash tree (Fraxinus excelsior), sessile oak, hop hornbeam, maple and among shrub species dogwood (Cornus 
sanguinea). The undergrowth is dominated by butcher's broom (Ruscus aculeatus) (Zorn, 1975).

\subsection{The study plots}

Two forest plots in the 30-35 year-old forest above the confluence of the Dragonja river and the Rokava river were selected for the current study. The first one was chosen on the north facing slope in the Rokava watershed $\left(1419 \mathrm{~m}^{2}\right)$ and the second one on the south facing slope in the Dragonja watershed $\left(615 \mathrm{~m}^{2}\right)$, about $400 \mathrm{~m}$ apart, both about $2500 \mathrm{~m}$ away from the village of Labor and about $200 \mathrm{~m}$ above sea level (Fig. 1). Between the village of Labor and both plots a chronosequence of natural reforestation has been identified from the 4-5 year-old forest near the village to the 30-35 year-old forest on the slopes near the plots (Šraj, 2003a). The surface area of the north plot is $1419 \mathrm{~m}^{2}$. There were 117 trees with a diameter at breast height $(D B H$ at $1.35 \mathrm{~m}) \geq 0.03 \mathrm{~m}$, counted in September 2000. This resulted in a stem density of 0.09 trees per square metre of forest floor. Hornbeam (Carpinus orientalis croaticus) represented almost half of all trees (47\%), followed by pubescent oak (Quercus pubescentis) (34\%), ash (Fraxinus ornus) (5\%), maple (Sorbus torminolis) (3\%), and other species (11\%). Mean ( \pm S.E.) tree height was $12.32( \pm 0.47) \mathrm{m}$ and mean $D B H$ was $0.14( \pm 0.01) \mathrm{m}$ (Te Linde, 2001). The undergrowth was dominated by butcher's broom (Ruscus aculeatus).

The south plot has an area of $615 \mathrm{~m}^{2}$ or approximately half the size of the north plot. Nevertheless, there are more trees on the south plot (191) than on the north plot, reflected in the stem density of 0.31 trees per square metre which was more than three times that of the north plot. More than half of the trees were ash trees (Fraxinus ornus) (54\%), followed by oak (Quercus pubescentis) (26\%), hornbeam (Carpinus orientalis croaticus) (4\%), maple (Sorbus torminolis) (2\%), and other species (14\%). The tree height could not be measured because of the high tree density but it was estimated at $8 \mathrm{~m}$ on average. The mean $D B H( \pm$ S.E.) for all species was $0.07( \pm 0.00) \mathrm{m}$. The south plot has a much more abundant undergrowth, diverse vegetation, it is drier, experiences high vapour pressure deficit and receives more radiant energy in comparison to the north plot (van der Tol et al., 2007).

\section{Measurements and methods of analysis}

\subsection{Precipitation above the canopy}

Precipitation above the canopy was measured on the south plot from October 2000 using a tipping bucket rain gauge $(0.2 \mathrm{~mm} / \mathrm{tip})$ and logged using an automatic digital data logger at 10-minute intervals (Campbell Scientific Ltd. 21-X data logger) in combination with a manual gauge for control (both set up on a tower $8 \mathrm{~m}$ above the grounds). In parallel, the precipitation was measured in the valleys of the Dragonja and Rokava (Fig. 1), directly downslope from both measuring plots with the same instruments. 


\subsection{Throughfall (Tf)}

Throughfall is the portion of precipitation which reaches the forest floor directly without touching the canopy (direct throughfall), and the portion of precipitation intercepted by the canopy which, after the storage capacity of the canopy has been filled, reaches the floor as crown drip (Bruijnzeel, 2000; Chang, 2003). Direct throughfall and crown drip cannot be measured separately, so that together they represent throughfall.

Throughfall is best measured using a combination of fixed and manual roving gauges to provide representative samples (Waterloo et al., 1999; Bruijnzeel, 2000). With manual roving gauges the so-called drip-points are included, where the $T f$ is higher than the precipitation (Chang, 2003).

In September 2000, two stainless steel gutters $(30 \times 370 \mathrm{~cm})$ were set up at ground level on each plot, equipped with a tipping bucket and a logger system $(0.051 /$ tip $)$ with digital recording of results every 10 minutes (Campbell Scientific Ltd. 21-X data logger) in combination with 10 manual roving gauges (Vrije Universiteit Amsterdam, diameter 11.28 $\mathrm{cm}$ ) that were emptied manually (twice per month on average) and moved randomly after each reading of water quantity on each plot separately. Despite the larger surface area of the north plot, the number of installed instruments was the same on both plots, due to the higher density of trees in the south plot.

\subsection{Stemflow $(S f)$}

Stemflow was measured on two individual trees of the two most typical species (i.e. on four trees) in each plot. On the north plot, oak and hornbeam trees were selected, and on the south plot ash and oak trees. Each tree was fitted with a rubber collar around the stem connected to a tipping bucket that was logged at 10-minute intervals (Campbell Scientific Ltd. 21-X data logger).

\subsection{Leaf area index (LAI)}

First, the specific leaf area (SLA) was estimated for the main species in order to estimate the leaf area index. The $S L A$ is an area-to-weight relationship $\left[\mathrm{m}^{2} / \mathrm{kg}\right]$. It was estimated for five most typical species for each plot separately and also for the "other leaves" category as well as for fine leaf material (leaves broken into unrecognizably small pieces). For this reason 100-300 fresh leaves were collected for each of the species. Leaves were collected from different height layers of the trees on both plots, but because of the large height of the trees on the north plot this sampling procedure was not applied entirely. The surface area was determined by way of scanning (resolution $300 \mathrm{dpi}$ ) and digital analyses, using photo-imaging software (Paint Shop Pro). All samples were then dried to a constant weight.

$L A I$ was estimated in two seasons, i.e. for $2000 / 01$ and 2001/02. It was estimated with one direct and two indirect methods. The direct technique for estimating the $L A I$ was collecting litterfall in season 2001/02. The litter was collected regularly (once or twice a month) in 10 randomly positioned plastic baskets on each plot. The surface area of each basket was $0.2 \mathrm{~m}^{2}$. The baskets were covered with nets to ensure drainage and to prevent rooting. Each season 10 
series were collected. The collected samples were first air- and then oven-dried $\left(70^{\circ} \mathrm{C}\right)$ to constant weight. Dried leaves were then sorted and weighed by species to the nearest $0.001 \mathrm{~g}$ for each basket separately. The total leaf area index was calculated from dry weights of individual species of each basket and SLA (Šraj, 2003b).

Hemispherical photography was one of the applied indirect methods also used in the season 2001/02. Hemispherical photographs of canopies were taken with a $28 \mathrm{~mm}$ lens at the same 10 points where the baskets were situated. Five series of photography were done in each season. Photographs were scanned at 300 dpi and converted to 1-bit images (black and white). The threshold value was estimated manually for each picture in order to distinguish between the canopy and the sky upon which the canopy gap fraction was computed. LAI was then calculated considering the Beer-Lambert Law and the Miller equation for foliage density (Miller, 1967; Chen et al., 2006).

The second indirect method applied was measurement of the photosynthetically active radiation $(P A R)$ with a Sunfleck Ceptometer. Only three series of measurements of PAR were made in October 2000 at the same 10 points where the baskets were positioned in the south plot. In the north plot, the method could not be applied because not enough sunlight reached the forest floor on the north facing slopes at this time of the year (Te Linde, 2001).

Because we only had three series of $P A R$ measurements, and the thresholding by the hemispherical photography was done manually and could be subjective so it can introduce errors (Nobis and Hunziker, 2005; Cescatti, 2007; Macfarlane et al., 2007), the results of the litterfall collection method were used as representative. This method is also believed by many other authors to give reliable results (Jonckheere et al., 2004; Eriksson et al., 2005).

\subsection{Other meteorological measurements}

Other measurements in the watershed are described in Te Linde (2001), Petkovšek and Mikoš (2004), Keestra et al. (2005) and van der Tol et al. (2007). There were several rain gauges arranged over the watershed and three meteorological stations in Boršt, Kubed and Portorož (Fig. 1) that measured incoming and outgoing radiation, temperature, relative humidity, wind velocity, direction, and precipitation.

\subsection{Gash's model of rainfall interception}

The analytical Gash model of rainfall interception (Gash, 1979; Gash et al., 1995) is based on Rutter's numerical model (Rutter, 1967) and has been successfully applied in many studies and different forest environments (Dolman, 1987; Loustau et al., 1992; Lankreijer et al., 1993; Gash et al., 1995; Carlyle-Moses and Price, 1999; Bruijnzeel and Wiersum, 2000; Shellekens, 2000). Gash's model considers rainfall to occur as a series of discrete events. The model distinguishes three phases: a wetting phase during which gross rainfall $(P)$ is less than the threshold value required to saturate the canopy $\left(P_{g}^{\prime}\right)$, a saturation phase, when rainfall intensity $(R)$ exceeds the evaporation rate from the wet canopy $(\bar{E})$, and a drying phase after 
the rainfall event. A series of equations are used in the model to calculate the interception loss during all three phases (Table 1) and requires knowledge of the canopy structure as described by the following parameters: the free throughfall coefficient $p$, which represents the proportion of gross precipitation that passes through the canopy without touching it, the canopy storage capacity $S$, the proportion of gross precipitation reaching the trunks $p_{t}$, and the trunk storage capacity $S_{t}$.

Table 1. Equations used in the revised analytical Gash interception model (Gash et al., 1995).

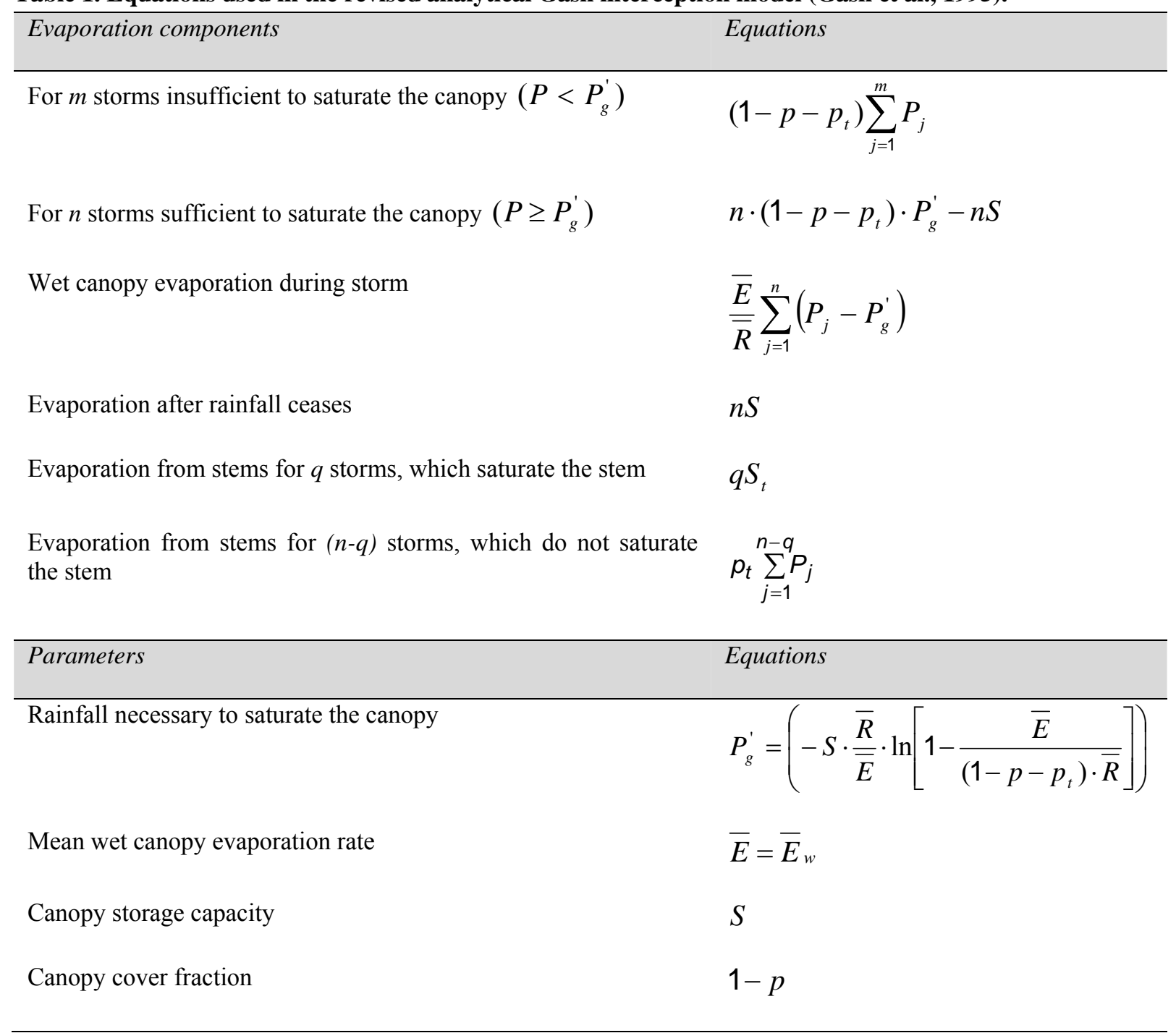

Free throughfall coefficient $p$ was estimated by the method of Jackson (Jackson, 1975) as the slope of the regression between gross rainfall and throughfall for storms that are too small to fill the canopy storage capacity $S$. It is assumed that evaporation losses during these storms are negligible.

Canopy storage capacity $S$ was estimated by the method of Leyton et al. (1967). A straight line with slope $\left(1-p_{t}\right)$ was drawn through the upper points of the throughfall versus gross rainfall graph for storms $\geq 1.5 \mathrm{~mm}$, assuming that these points represented conditions with minimal evaporation losses. $S$ was obtained as the negative intercept of that line with throughfall axis. 
The stemflow parameters $S_{t}$ and $p_{t}$ were estimated in accordance with Gash and Morton (1978), as the negative intercept and the slope of linear regression line between stemflow and gross rainfall.

All parameters were estimated separately for four vegetation periods: (1) leaf-fall period (October 15-December 20), (2) leafless period (December 21-March 31), (3) leafing-out period (April 1-April 30), (4) full-leaf period (May 1-October 14). The periods were determined according to the results of measurements of the leaf area index on the research plots and the phenological data of the nearest phenological stations. The ratio of mean wet canopy evaporation rate $\left(\bar{E}=\bar{E}_{w}\right)$ over average rainfall intensity $(\bar{R})$ was estimated as the slope of the canopy interception loss versus gross precipitation regression relationship after Gash (1979). $\bar{E}$ can be estimated in this way from $\bar{R}$ in the absence of above-canopy climatic observations (Rowe, 1983; Bruijnzeel and Wiersum, 1987; Dykes, 1997; Shellekens et al., 1999). A regression analysis was made for each month separately.

The aerodynamic resistance $\left(r_{a}\right)$ of both forests to evaporation was calculated using the following equation for closed canopies under neutral stability conditions (Thom, 1975):

$$
r_{a}=\frac{\left(\ln \frac{z-d}{z_{0}}\right)^{2}}{k^{2} \cdot u_{z}}
$$

where $z$ is the height of windspeed measurement, $d$ is the zero plane displacement height, $z_{0}$ the roughness length of the forest, $k$ is von Karman's constant $(0.41)$ and $u_{z}$ is wind speed above the canopy. Values of $d$ and $z_{0}$ were estimated as 0.75 and 0.10 of the mean stand height, respectively (Gash, 1979; Dolman, 1986; Valente et al., 1997; Allen et al., 1998; Pypker et al., 2005). Measurements of windspeed were taken from the nearby meteorological station Boršt. The windspeed at $2 \mathrm{~m}$ above the forest was calculated following Allen et al. (1998) to adjust the data from the meteorological station at the height of $12 \mathrm{~m}$ to the standard 2 m (Dykes, 1997; Llorens, 1997).

\section{Results and discussion}

\subsection{Rainfall}

Between October 5, 2000 and September 12, 2001, a total of $1318 \mathrm{~mm}$ of rainfall was measured in the south plot, distributed over 139 rainy days and 199 events. The events were separated by periods without rain, in which canopies could dry out. The amount of rainfall per event was between 0.2 and $100.2 \mathrm{~mm}$, the duration of rainfall event varied from 5 minutes to 39.5 hours and the intensity varied between 0.2 and $44.7 \mathrm{~mm} / \mathrm{h}$. The average amount of rainfall per event ( \pm standard error) was $6.6( \pm 0.9) \mathrm{mm}$ and the average duration and intensity of the event were $3.8( \pm 0.4)$ hours and $2.5( \pm 0.3) \mathrm{mm} / \mathrm{h}$, respectively. No snowfall was detected. 
Precipitation intensity differs between seasons (Table 2). The highest mean precipitation intensity ( \pm standard error) was identified for the summer-time period, i.e. $4.0( \pm 1.2) \mathrm{mm} / \mathrm{h}$, this being a consequence of summer convectional showers. In winter, the mean intensity was $1.2( \pm 0.2) \mathrm{mm} / \mathrm{h}$, almost four times lower than in summer.

Compared to the 35-year mean monthly precipitation (1961-1995) measured in Portorož, the study period showed significant deviations from the climate average, especially in the autumn months. In October and November 2000 there was $492 \mathrm{~mm}$ of rainfall, twice the 35-year average in Portorož and a third of the locally measured precipitaton in the measuring period. Worth mentioning is an extreme event on November 3/4, 2000, when the rainfall of $100.2 \mathrm{~mm}$ almost equalled the mean monthly long-term total rainfall for November.

Regression analyses between the daily precipitation at respective rain gauges (south plot, Dragonja and Rokava) indicated high correlation with $R^{2}>0.97$ (Fig. 2). Statistical tests gave $p$-values (significance $F$ ) of linear regression less than 0.0001 for both regressions. So we could conclude that there was a significant linear relationship between the daily precipitation at those rain gauges. Due to the technical problems related to tree height, the measurements in the north plot did not start until 2002. For both plots the precipitation values measured in the south plot were considered, which seemed admissible due to the small distance between the plots and good correlation between the precipitation stations.

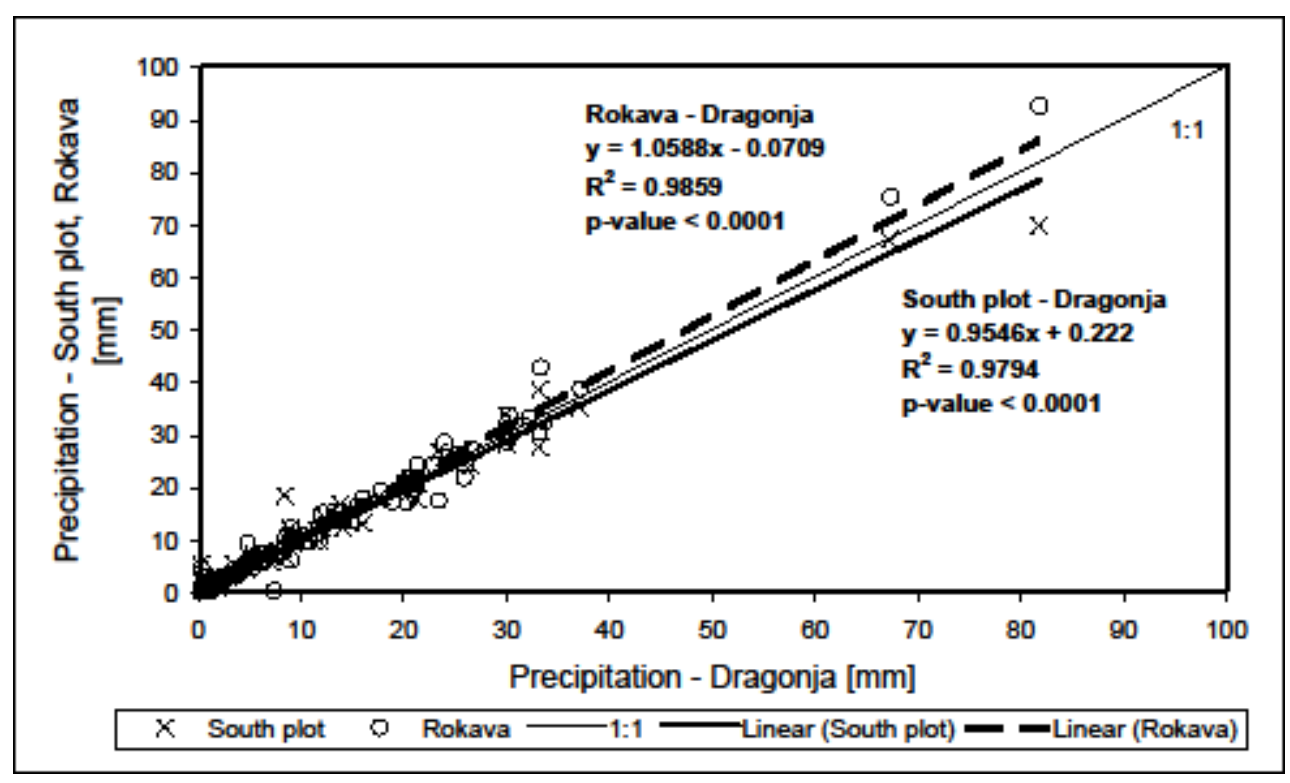

Fig. 2. Regression analyses of the daily precipitation between the south plot and the Dragonja rain gauges $(n=120)$ and between the Rokava and the Dragonja rain gauges $(n=338)$. 
Table 2. Measured values ( \pm standard error) of forest hydrological cycle for the period 5/10/2000 12/9/2001 for the south and north plot, respectively.

\begin{tabular}{|c|c|c|c|c|c|}
\hline & $\begin{array}{c}P \\
\text { (from the south } \\
\text { plot) } \\
{[\mathrm{mm}]}\end{array}$ & $\begin{array}{c}\text { Mean rainfall } \\
\text { intensity } \\
{[\mathrm{mm} / \mathrm{h}]}\end{array}$ & $\begin{array}{c}\text { Corrected } \\
T f \\
{[\mathrm{~mm}]}\end{array}$ & $\begin{array}{c}S f \\
{[\mathrm{~mm}]}\end{array}$ & $\begin{array}{c}\text { Interception loss } \\
{[\mathrm{mm}]}\end{array}$ \\
\hline \multicolumn{6}{|l|}{ South plot } \\
\hline $\begin{array}{l}\text { Leaf-fall } \\
\text { period }\end{array}$ & $479.6 \pm 2.3$ & $3.4 \pm 0.9$ & $\begin{array}{l}301.7 \pm 1.5 \\
(62.9 \% \mathrm{P})\end{array}$ & $\begin{array}{c}20.9 \pm 0.1 \\
(4.4 \% \mathrm{P})\end{array}$ & $\begin{array}{l}157.0 \pm 0.7 \\
(32.7 \% \mathrm{P})\end{array}$ \\
\hline $\begin{array}{l}\text { Leafless } \\
\text { period }\end{array}$ & $375.0 \pm 1.2$ & $1.2 \pm 0.2$ & $\begin{array}{c}275.3 \pm 1.0 \\
(73.4 \% \mathrm{P})\end{array}$ & $\begin{array}{l}18.1 \pm 0.1 \\
(4.8 \% \mathrm{P})\end{array}$ & $\begin{array}{l}81.6 \pm 0.2 \\
(21.8 \% \mathrm{P})\end{array}$ \\
\hline $\begin{array}{l}\text { Leafing-out } \\
\text { period }\end{array}$ & $273.2 \pm 1.2$ & $2.2 \pm 0.3$ & $\begin{array}{l}162.3 \pm 0.7 \\
(59.4 \% \mathrm{P})\end{array}$ & $\begin{array}{l}11.4 \pm 0.1 \\
(4.2 \% \mathrm{P})\end{array}$ & $\begin{array}{l}99.6 \pm 0.6 \\
(36.4 \% \mathrm{P})\end{array}$ \\
\hline $\begin{array}{l}\text { Full-leaf } \\
\text { period }\end{array}$ & $190.8 \pm 2.4$ & $4.0 \pm 1.2$ & $\begin{array}{l}145.9 \pm 2.2 \\
(76.5 \% \mathrm{P})\end{array}$ & $\begin{array}{l}9.0 \pm 0.1 \\
(4.7 \% \mathrm{P})\end{array}$ & $\begin{array}{l}35.9 \pm 0.4 \\
(18.8 \% \mathrm{P})\end{array}$ \\
\hline Annual & $1318.6 \pm 0.9$ & $2.5 \pm 0.3$ & $\begin{array}{c}885.2 \pm 0.6 \\
(67.1 \% \mathrm{P}) \\
\end{array}$ & $\begin{array}{c}59.31 \pm 0.1 \\
(4.5 \% \mathrm{P})\end{array}$ & $\begin{array}{l}374.1 \pm 0.3 \\
(28.4 \% \mathrm{P})\end{array}$ \\
\hline \multicolumn{6}{|l|}{ North plot } \\
\hline $\begin{array}{l}\text { Leaf-fall } \\
\text { period }\end{array}$ & $457.0^{*} \pm 2.3$ & $2.7 \pm 0.5$ & $\begin{array}{r}315.5 \pm 1.7 \\
(69.0 \% \mathrm{P})\end{array}$ & $\begin{array}{c}16.0 \pm 0.1 \\
(3.5 \% \mathrm{P})\end{array}$ & $\begin{array}{l}125.5 \pm 0.5 \\
(27.5 \% \mathrm{P})\end{array}$ \\
\hline $\begin{array}{l}\text { Leafless } \\
\text { period }\end{array}$ & $375.0 \pm 1.2$ & $1.2 \pm 0.2$ & $\begin{array}{r}267.8 \pm 1.0 \\
(71.4 \% \mathrm{P})\end{array}$ & $\begin{array}{r}11.1 \pm 0.0 \\
(3.0 \% \mathrm{P})\end{array}$ & $\begin{array}{l}96.1 \pm 0.2 \\
(25.6 \% \mathrm{P})\end{array}$ \\
\hline $\begin{array}{l}\text { Leafing-out } \\
\text { period }\end{array}$ & $196.2 * \pm 1.6$ & $1.9 \pm 0.3$ & $\begin{array}{r}112.5 \pm 1.1 \\
(57.4 \% \mathrm{P})\end{array}$ & $\begin{array}{l}3.5 \pm 0.0 \\
(1.8 \% \mathrm{P})\end{array}$ & $\begin{array}{l}80.2 \pm 0.8 \\
(40.8 \% \mathrm{P})\end{array}$ \\
\hline $\begin{array}{l}\text { Full-leaf } \\
\text { period }\end{array}$ & $183.8^{*} \pm 2.3$ & $4.5 \pm 1.5$ & $\begin{array}{r}172.3 \pm 3.2 \\
(93.7 \% \mathrm{P})\end{array}$ & $\begin{array}{l}4.5 \pm 0.1 \\
(2.5 \% \mathrm{P})\end{array}$ & $\begin{array}{l}7.0 \pm 0.7 \\
(3.8 \% \mathrm{P})\end{array}$ \\
\hline Annual & $1212.0 * \pm 0.9$ & $2.3 \pm 0.3$ & $\begin{array}{c}868.1 \pm 0.8 \\
(71.5 \% \mathrm{P})\end{array}$ & $\begin{array}{l}35.0 \pm 0.0 \\
(2.9 \% \mathrm{P})\end{array}$ & $\begin{array}{c}308.9 \pm 0.3 \\
(25.4 \% \mathrm{P})\end{array}$ \\
\hline
\end{tabular}

\subsection{Throughfall}

Regression analyses between fixed and roving gauge measurements were made for each plot and for the growing and leafless seasons. A comparison of the two methods showed that the roving gauges in the full growing season indeed gave larger amounts of $T f$ with $R^{2}$ values of over 0.98 (Fig. 3), with the exception of throughfall values less than $2.5 \mathrm{~mm}$ on the north plot. The statistical tests gave $p$-values (significance $F$ ) of linear regression less than 0.0001 for both regressions presented. That means that there was very strong evidence that a linear relationship existed between the fixed and roving gauge measurements. On the basis of regression equations the $T f$ quantities measured with fixed gauges were corrected, with the exception of throughfall values less than $2.5 \mathrm{~mm}$. The mean annual corrected $T f$ value ( \pm standard error) on the south plot was $67.1( \pm 9.6) \%$ of incoming rainfall, and on the north plot $71.5( \pm 11.6) \%$. The lower value on the south plot was expected and was the consequence of the higher tree density. 


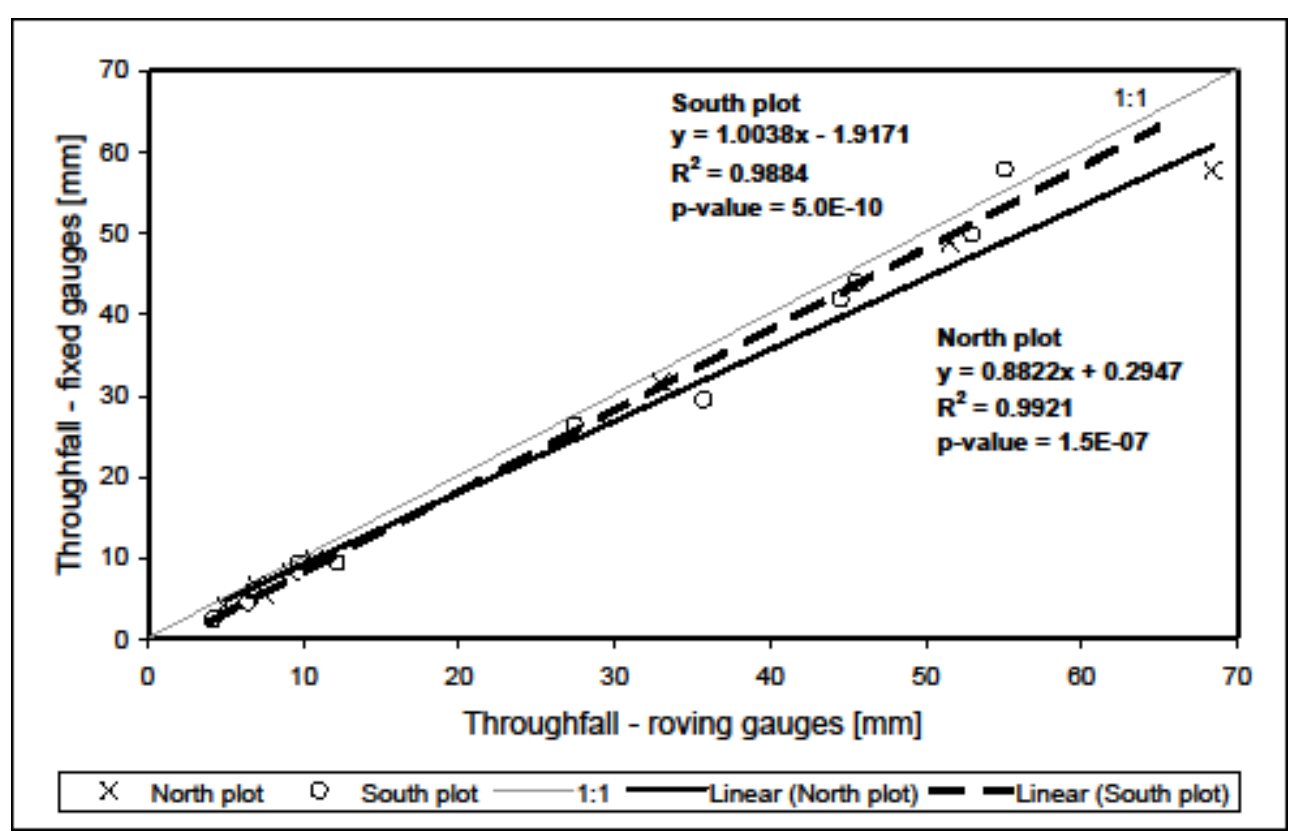

Fig. 3. Regression analyses between fixed and roving gauge measurements of throughfall for the full growing season on south and north plot, respectively.

By comparing the results according to season, the values were very similar on both plots, except in summer when there were $17 \%$ higher quantities on the north plot (Table 2). This may be attributed to the so-called "drip-points", where rain drops become concentrated at the edge of the crown and where throughfall might be even higher than gross rainfall (Bruijnzeel, 2000; Chang, 2003). Since the trees in the north plot are less dense and in general the edges of their crowns do not overlap, consequently in summer, i.e. in the period of full growth, the phenomenon is even more pronounced. The highest Tf values are expected during winter, when there is no foliage and when a large proportion of precipitation reaches the ground. However, the results of the measurements show the highest values in summer, and that on both plots. The underlying reason is the high intensity of precipitation (on average approx. 4.0 $\pm 1.2 \mathrm{~mm} / \mathrm{h}$ per event), which occurs as a result of summer convective showers. The comparison of the autumn and spring quantities also shows the dependence upon precipitation intensity. Autumn $T f$ values are higher than during the spring, corresponding to the higher precipitation intensity.

The measured values are comparable with those found in other similar studies for deciduous forests, although they are about $10 \%$ lower (Table 3). For the deciduous forest in Canada, Carlyle-Moses and Price (1999) estimated the $T f$ value at $76.4 \%$, Dolman (1987) for oak forest in the Netherlands an average of $77 \%$, and for the deciduous forest in the Netherlands Lankreijer et al. (1993) estimated the value at 77-82\% (Table 3). Tf values for coniferous forests are higher (67-87\%) and the values for tropical forests are 45-81\% (Table 3). 
Table 3. Review of measured values of the runoff share through canopy ( $T f$ from various research studies for different forest types.

\begin{tabular}{|c|c|c|c|}
\hline Forest type & Tf [\%] & Location & Author \\
\hline $\begin{array}{l}\text { Deciduous } \\
\text { mediterranean forest }\end{array}$ & $67-72$ & Slovenia & this study \\
\hline Oak forest & $\begin{array}{l}57-77 \text { (with foliage) } \\
80-87 \text { (without foliage) }\end{array}$ & The Netherlands & Dolman (1987) \\
\hline Deciduous forest & $77-82$ & The Netherlands & Lankreijer et al. (1993) \\
\hline $\begin{array}{l}\text { Deciduous forest } \\
\text { (oak, maple, hornbeam) }\end{array}$ & $76.4 \pm 2.9$ & Canada & $\begin{array}{l}\text { Carlyle-Moses and } \\
\text { Price (1999) }\end{array}$ \\
\hline $\begin{array}{l}\text { Leafy evergreen forest } \\
\text { (eucalyptus) }\end{array}$ & 88.5 & Portugal & Valente et al. (1997) \\
\hline Mixed evergreen forest & $63-76$ & New Zealand & Rowe (1983) \\
\hline Coniferous forest & 87.1 & SW France & Gash et al. (1995) \\
\hline Coniferous forest & 83.2 & Portugal & Valente et al. (1997) \\
\hline Coniferous forest & $\begin{array}{c}77.4-82.6 \text { (in summer) } \\
75.8-81.7 \text { (in winter) }\end{array}$ & France & Loustau et al. (1992) \\
\hline Coniferous forest & 67 & E Great Britain & $\begin{array}{l}\text { Gash and Stewart } \\
(1977)\end{array}$ \\
\hline Tropical forest (acacia) & $75.4-80.9$ & Indonesia & $\begin{array}{ll}\text { Bruijnzeel } & \text { and } \\
\text { Wiersum (1987) }\end{array}$ \\
\hline Tropical rain forest & 81 & Indonesia & Dykes (1997) \\
\hline Tropical rain forest & 45.5 & Puerto Rico & Schellekens (2000) \\
\hline Tropical rain forest & $78-79$ & $\mathrm{~S}$ America & Jetten (1996) \\
\hline
\end{tabular}

\subsection{Stemflow}

The average stemflow fraction ( \pm standard error) amounted to $4.5( \pm 0.8) \%$ and $2.9( \pm 0.6) \%$ of the associated rainfall for the south and north plot, respectively. The difference was a result of the different structure and characteristics of forests on both slopes. Higher values of stemflow on the south plot corresponded well with the higher tree density. In the literature the highest stemflow rates have been consistently reported for high tree densities (Loustau et al., 1992) because of three factors: (1) Shorter branches in such a forest enable faster outflow, therefore lower evaporation and higher stemflow. (2) Tree height - the height and $D B H$ of the oak trees on the north plot were more than twice the values on the south plot. That means longer storage time, larger storage capacity of the trunks and consequently lower stemflow. (3) Last but not least, ash trees on the south plot with their smooth bark enabled faster outflow and had lower retention.

By considering the stemflow by seasons, it can be established that in the south plot the stemflow did not vary significantly with season (winter $4.83 \%$ and summer $4.17 \%$ ), however in the north plot stemflow was highest in autumn (3.49\%) and lowest in spring $(1.76 \%)$ (Table 2).

Comparison of stemflow between different tree species confirmed that the stemflow on the south plot from ash trees was more than double that by oak trees, probably due to the smoother bark of the ash trees, which enables a quicker outflow and lower retention. Roughbarked species typically have low stemflow values (Jackson, 1974; Pypker et al., 2005). With larger amounts of precipitation (above $30 \mathrm{~mm}$ ) the difference was reduced approximately by half, as the larger storage capacity of oak trunks was exceeded at higher precipitation. The stemflow emerged with a specific time-lag according to the precipitation, because of the 
canopy and trunk storage capacity. The results showed that the stemflow occurs after approx. 0.6-1.8 $\mathrm{mm}$ of rain (according to the vegetation period and plot), and does not occur with smaller precipitation amounts. The value met well with the estimated storage capacity of the canopy and trunks, which was between 0.3 and $1.4 \mathrm{~mm}$.

These measured values are similar to other studies, e.g. for the deciduous forest in Canada, Carlyle-Moses and Price (1999) estimated the stemflow at $4.3 \%$ (1987) and Dolman (1987) $0-5 \%$ of precipitation for oak forest in the Netherlands.

\subsection{Leaf area index (LAI)}

Table 4 shows that the specific leaf areas (SLA) of each tree species in the north plot were larger than on the south plot, with the exception of hornbeam leaves. The differences in the SLA of the same species on both plots were estimated at $2 \%$ (oak tree) and $30 \%$ (dogwood), respectively. These differences could be explained by the differences in growing conditions (water and light availability) (van der Tol et al., 2007) on both plots and could also be in less marked manner the consequence of sampling of fresh leaves. SLA usually increases with depth in the canopy due to the adaptation of leaves to the lower light availability. In the literature, values of specific areas for deciduous tree species are rare, one of the reasons being that, in the majority of the studies, the indirect method of $L A I$ determination was applied, where determination of the specific leaf area is not necessary. The other reason is the time required for the method. For an approximate comparison only the values of Chason et al. (1991) were found, who estimated the SLA value for the oak tree at $10-12 \mathrm{~m}^{2} / \mathrm{kg}$, and 16.5 $\mathrm{m}^{2} / \mathrm{kg}$ for the red maple tree.

The leaf area index LAI was estimated by three methods. Most foliage in the Dragonja watershed was lost from the beginning of November to the end of December. The mean maximum values of $L A I$ by litterfall method were estimated at 6.6 and 6.9 for the south and north plots, respectively (at the height of the growing period) (Fig. 4). A smaller value of $L A I$ on the sunlit south plot was the consequence of growing conditions (less water availability) (van der Tol et al., 2007) of this forest.

Table 4. Specific leaf area (SLA) ( \pm standard error) for each tree species in the south and north research plots.

\begin{tabular}{lcc} 
Species & $\begin{array}{c}\text { South plot } \\
{\left[\mathrm{m}^{2} \mathrm{~kg}^{-1}\right]}\end{array}$ & $\begin{array}{c}\text { North plot } \\
{\left[\mathrm{m}^{2} \mathrm{~kg}^{-1}\right]}\end{array}$ \\
\hline Oak & $15.95^{*}$ & $16.25^{*}$ \\
Hornbeam & $30.60^{*}$ & $26.27^{*}$ \\
Maple & $32.41 \pm 0.70$ & $37.61 \pm 1.66$ \\
Ash & $36.61 \pm 0.87$ & $48.90 \pm 1.21$ \\
Dogwood & $30.63 \pm 0.78$ & $43.47 \pm 2.46$ \\
Other leaves & $26.55 \pm 11.13$ & $27.68 \pm 1.66$ \\
Fine leaf material & $5.35^{*}$ & $5.01^{*}$ \\
\hline *Te Linde (2001) & &
\end{tabular}




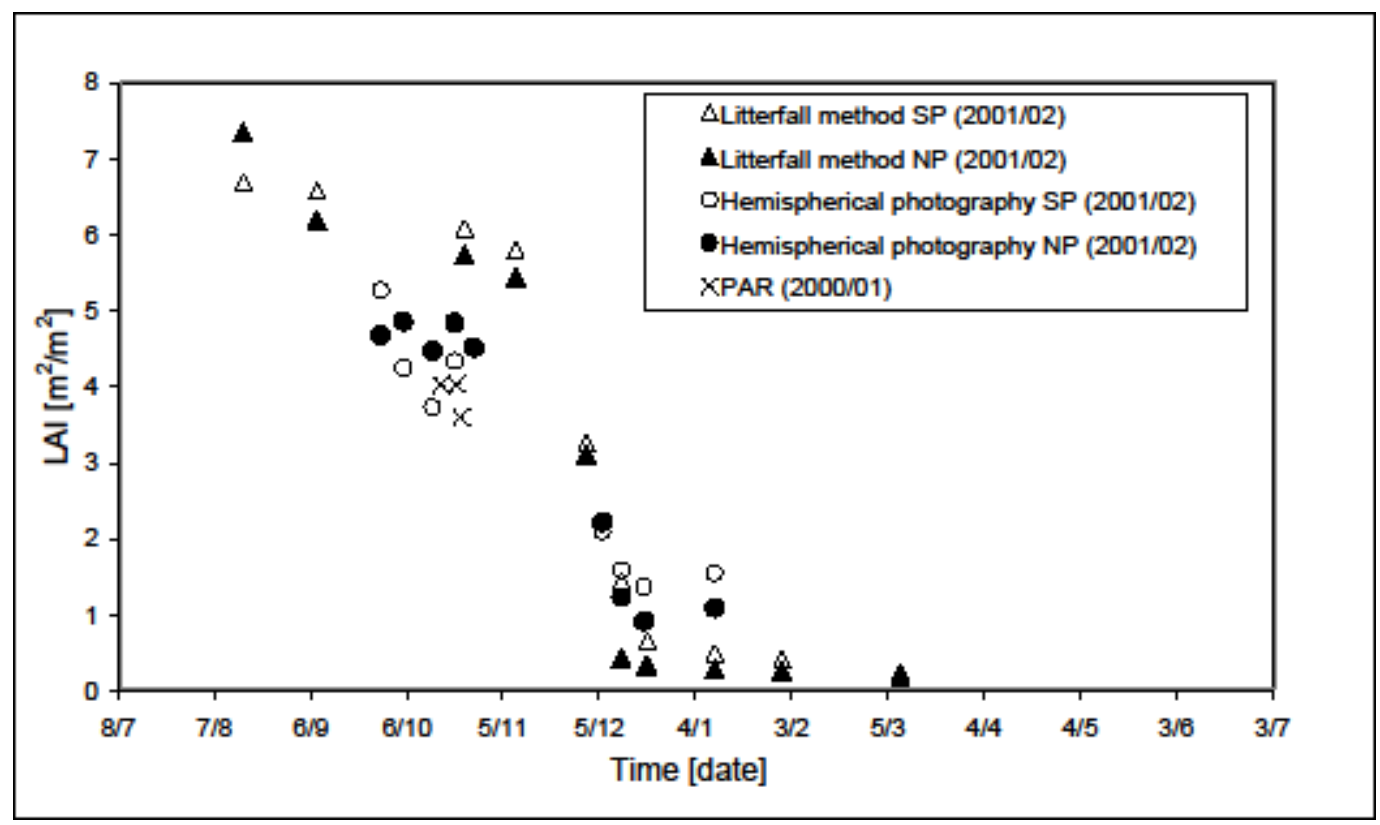

Fig. 4. Comparison of three different methods of LAI estimation on the south (SP) and the north plot

(NP).

A comparison of the three methods during a short period (October, 20-23) (Table 5), in which all three sets of measurements were carried out simultaneously, shows that the highest values are gained with the litterfall collection method, and the lowest with measuring the photosynthetic active radiation $(P A R)$. In the PAR measurements the $L A I$ is almost $50 \%$ lower, and on average $L A I$ using hemispherical photography is approx. $20 \%$ lower than the litterfall collection method (Table 5). Both indirect methods under-estimate the $L A I$ values. Similar conclusions have been reached by other researchers worldwide (Chason et al., 1991; Chen et al., 1997, Levy and Jarvis, 1999). For mixed deciduous forest (oak, hickory, maple) Chason et al. (1991) estimated the $L A I$ value at 4.89 according to the litterfall collection method, and with two different indirect radiation penetration methods (light transmission measurements; light interception) 3.79 and 2.91, respectively.

Table 5. Comparison of different LAI values ( \pm standard error) according to different methods during October, 20-23 (adopted from Šraj, 2004).

\begin{tabular}{lccc} 
& Litterfall collection & Hemispherical photography & PAR measurements \\
\hline North plot & $5.70( \pm 0.07)$ & $4.81( \pm 0.05)$ & - \\
South plot & $6.05( \pm 0.08)$ & $4.31( \pm 0.11)$ & $3.82( \pm 0.18)$ \\
\hline
\end{tabular}

\subsection{The interception loss}

On the basis of the measurements and water balance equation the average annual interception losses ( \pm standard error) were estimated to be $28.4( \pm 4.1)$ and $25.4( \pm 4.0) \%$ of precipitation for the south and north slopes, respectively. The lower value on the north plot was in accordance with what should be expected, as tree density on the north plot was much lower. The lower density of the trees results in suppressed evaporation during storms because of the reduction in canopy area for evaporation (Gash et al., 1995; Pypker et al., 2005). However, 
both values were rather high compared with the interception losses of deciduous forests, which are usually between 15 and $25 \%$ (Bruijnzeel, 2000). In their research on deciduous forest in Canada, Carlyle-Moses and Price (1999) estimated the amount of the evaporated throughfall at $19.3 \%$, Dolman (1987) for oak forest in the Netherlands at an average of $23 \%$, and Lankreijer et al. (1993) for the deciduous forest in the Netherlands 18-23\%. In reality, the losses were even higher in this study, since the measured precipitation was not corrected for the systematic error of the point precipitation measurements with a standard raingauge. The systematic error occurs mostly due to the aerodynamic effects and its range is between 10 and $30 \%$ (Bonacci, 1991).

The comparison between different seasons (Table 2) showed similarities between both the plots, with the exception of summer, when there was a five-fold difference between both plots. In summer, the interception loss in the south plot was estimated at $18.8 \%$, and in the north plot $3.8 \%$, respectively. This was expected, since the south plot is much more exposed to solar radiation (van der Tol et al., 2007). The highest values of interception loss were in spring, the lowest in summer. Low summer values were a consequence of the high precipitation intensity in summer time, corresponding to high $T f$ values in the respective period.

\subsection{Wind influence}

The average values of wind speed and direction for single precipitation events were calculated from the average hourly speed and wind direction at the Portorož meteorological station. The analysis has shown that during precipitation events the south-east wind (jugo) had the most frequent occurrence, i.e. it occurred in 96 events out of 199 or almost in 50 \% (Fig. 5; Table 6). Other winds greatly lagged behind. The highest mean speed had the north-east wind (bora) $4.7 \mathrm{~m} / \mathrm{s}$, the south-east wind (jugo) was in the fourth place with almost $3 \mathrm{~m} / \mathrm{s}$ (Fig. 5). The jugo is a warm and humid wind of moderate strength in the Adriatic Sea that blows from the sea towards the coast, usually accompanied by cloudy and rainy weather (Krajcar, 2003). Generally, the causes of the jugo wind are related to the passage of deep frontal zones across the Adriatic Sea.

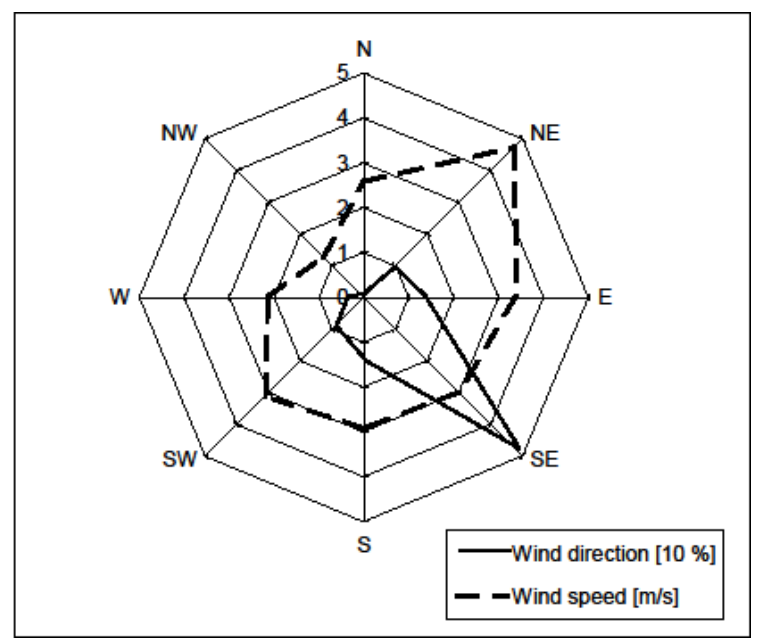

Fig. 5. Wind direction occurrence and average wind speed for each direction. 
Table 6. Analysis of wind speed ( \pm standard error) and wind directions during 199 precipitation events in the measurement period.

\begin{tabular}{ccccl}
\hline Direction & No. of events & Portion [\%] & Mean velocity [m/s] & Name of the wind \\
\hline N & 2 & 1.01 & $2.58 \pm 1.48$ & north wind \\
NE & 18 & 9.05 & $4.74 \pm 0.51$ & north-east wind (the bora) \\
E & 26 & 13.07 & $3.38 \pm 0.34$ & east wind \\
SE & 96 & 48.24 & $2.98 \pm 0.18$ & south-east wind (jugo) \\
S & 29 & 14.57 & $2.93 \pm 0.34$ & south wind \\
SW & 19 & 9.55 & $3.11 \pm 0.42$ & south-west wind \\
W & 8 & 4.02 & $2.14 \pm 0.64$ & west wind \\
NW & 1 & 0.50 & 1.30 & north-west wind (mistral) \\
\hline Sum & 199 & 100.00 & - & -
\end{tabular}

The influence of wind on intercepted precipitation can be significant not only because of increasing the evaporation but also because of reducing the storage capacity. If the wind speed is high enough, it increases tree motion, crown drip and indirect $T f$, and so reduces the storage capacity of the canopy. This is also shown by a classification decision tree model for the south plot generated with machine learning method J4.8 implemented in the WEKA system (Witten and Frank, 2000). Machine learning generated models are mostly used for prediction or forecasting and extracting new knowledge about observed processes (Atanasova and Kompare, 2002; Stravs et al., 2007).

The model attributes for each event were: gross precipitation, temperature, wind speed, wind direction and precipitation intensity. The modelled variable was $T f$ as a percentage of the gross precipitation, classified into 6 classes: $T f \_0$ (no throughfall), Tf_1_20 (throughfall between 1 and $20 \%$ of gross precipitation), Tf_21_40,Tf_41_60,Tf_61_80,Tf_81_100. The model recognized the quantity of precipitation as the most important parameter (top decision node) influencing the portion of throughfall. Events with precipitation less than $2.4 \mathrm{~mm}$ had no, or only a low portion of Tf $(0-20 \%)$, with the exception of non-foliated period or winter (temperature $<14^{\circ} \mathrm{C}$ ), when $T f$ was between 41 and $60 \%$. Events with gross precipitation between $2.4 \mathrm{~mm}$ and $7 \mathrm{~mm}$ had the $T f$ portion of $41-60 \%$. The model recognized the wind speed as an important parameter influencing the throughfall at events with more than $7 \mathrm{~mm}$ of gross precipitation. When the wind speed was lower than $4.1 \mathrm{~m} / \mathrm{s}$ and the precipitation intensity was lower than $9.6 \mathrm{~mm} / \mathrm{h}$, the Tf portion was $61-80 \%$. At events with higher intensity, the $T f$ portion was higher (81-100\%). Those values correspond well to the measured $T f$ values (Table 2). The throughfall values in summer time period were higher because of the high precipitation intensity of summer showers (Table 2). On the other hand, the model estimated the lower portion of throughfall by one or even two classes at the events with more than $7 \mathrm{~mm}$ of precipitation and wind speed higher than $4.1 \mathrm{~m} / \mathrm{s}$. The same phenomenon was determined by regression analysis of precipitation and throughfall (Fig. 6). 


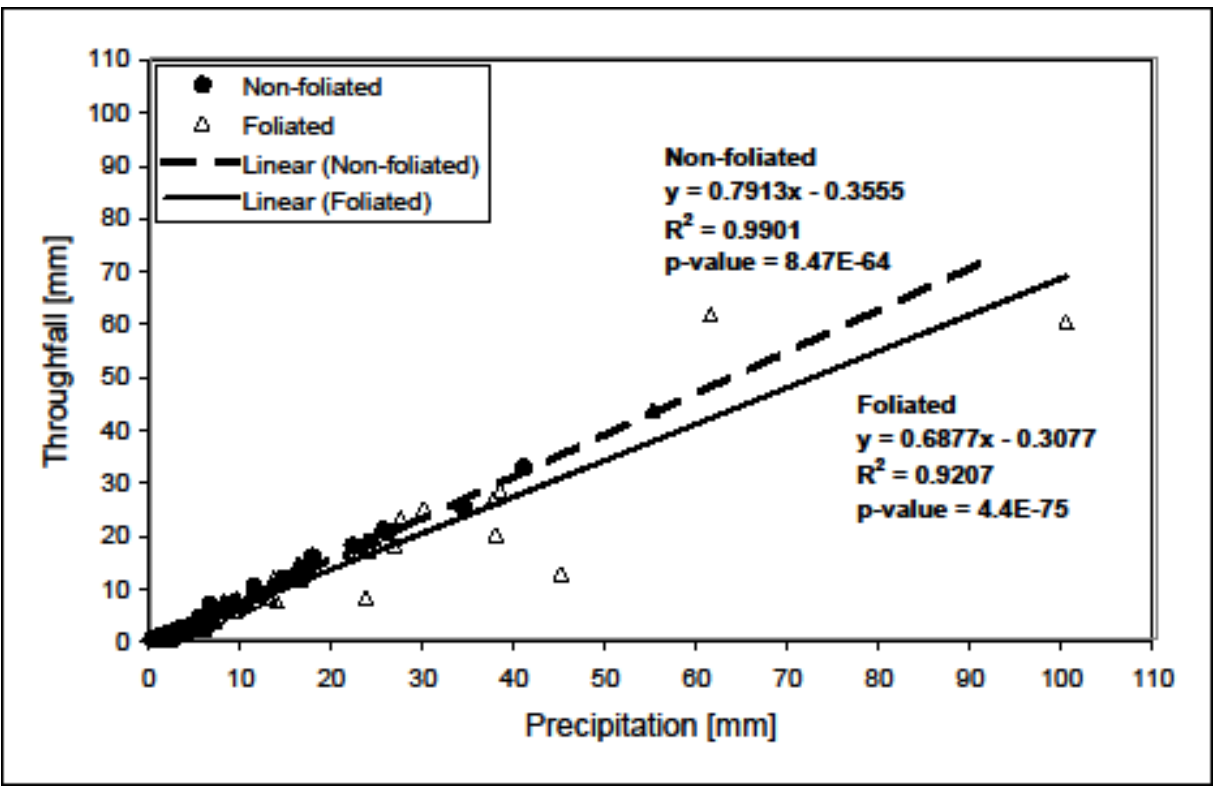

Fig. 6. Regression analyses between throughfall and gross precipitation for foliated $(n=135)$ and nonfoliated period $(n=64)$ on the south plot.

With the regression analyses the estimated throughfall in the foliated period for the south plot was about $70 \%$ of gross precipitation with the $R^{2}$ value of 0.92 (Fig. 6). On the other hand, in the non-foliated period the estimated throughfall was about $80 \%$ of gross precipitation with the $R^{2}$ value of 0.99 (Fig. 6). Statistical tests gave $p$-values (significance $F$ ) of linear regression less than 0.0001 for both regressions, so there was very strong evidence of a linear relationship. The values are comparable with measured throughfall values in the foliated periods (59.4-76.5\%) and in the leafless period (73.4\%) (Table 2).

With regression analysis of the measured data in the foliated period for the south plot it was established that at precipitation events with the south-east wind (jugo) with a velocity higher than $4 \mathrm{~m} / \mathrm{s}$, unusually low throughfall occurred (Fig. 7, The statistical test gave $p$-value < 0.05 , so evidence of a linear relationship existed. In these cases, the increased evaporation and thus lower throughfall might be the result of the local rise in temperature, deriving from the warm east-south wind, which has a characteristic air humidity and temperature rise (Fig. 8) (Krajcar, 2003). At the same time this was not significant for the precipitation events with other wind directions ( $p$-value $>0.7$ ) (Fig. 7). The same phenomenon was identified in the north plot, however in a less marked manner ( $T f$ was on average by about $20 \%$ higher than on the south plot). On the other hand, in the non-foliated period no such deviations were observed (Fig. 6). The regression analysis between throughfall and precipitation intensity gave a positive relationship for all wind directions - throughfall was slightly increased with higher precipitation intensity and the analysis between precipitation intensity and wind velocity showed no linear correlation $\left(R^{2}=0.0001, p\right.$-value $\left.=0.94\right)$. 


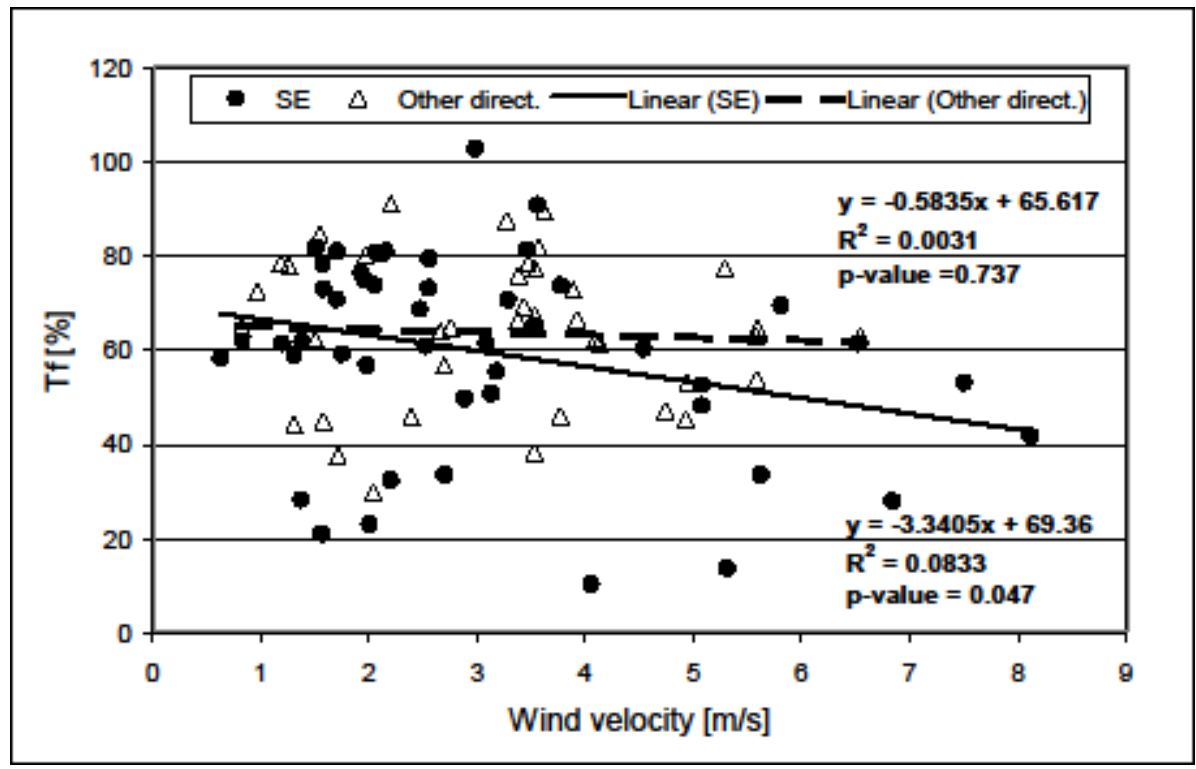

Fig. 7. Regression analyses between percentage of throughfall and wind velocity in the foliated period on the south plot for the south-east wind $(n=48)$ and other wind directions $(n=39)$ separately.

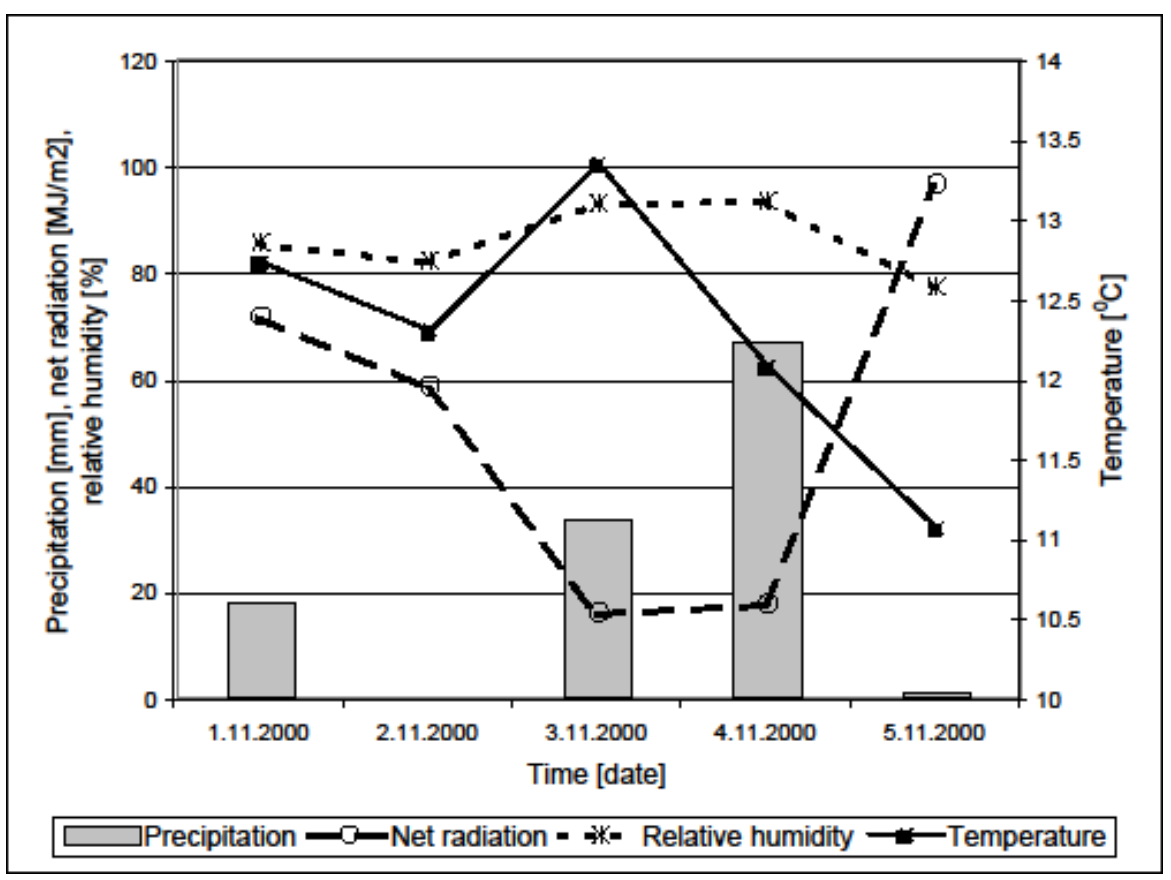

Fig. 8. Evolution of meteorological parameters during a typical SE wind episode and precipitation event 3/11/2000 0:40 - 4/11/2000 16:00 (average windspeed $4.5 \mathrm{~m} / \mathrm{s}$, max. wind speed 17.6 m/s).

\subsection{Gash's model of rainfall interception}

All vegetation and meteorological parameters were determined from the measured data for the north and south plot, respectively, and for the four vegetation periods.

The free throughfall coefficient $p$ was between 0.06 (the full-leaf period) and 0.57 (leaf-less period) on the south plot and between 0.20 and 0.83 on the north plot (Table 7). The comparison of values on both research plots shows somewhat higher values in the north plot, which corresponds to a smaller canopy cover and is a result of the lower density of trees in the area. Comparable results were obtained also in other similar studies. Dolman (1987) estimated 
the $p$ value between 0.3 and 0.8 for oak forest in the Netherlands, Lankreijer et al. (1993) 0.31 for the deciduous forest in the Netherlands and Carlyle-Moses and Price (1999) determined the $p$ value between 0.14 and 0.19 for the deciduous forest in Canada.

The canopy storage capacity $S$ was found to be between $0.4 \mathrm{~mm}$ (leaf-less period) and $1.2 \mathrm{~mm}$ (the full-leaf period) on the south plot and between 0.2 and $1.3 \mathrm{~mm}$ on the north plot (Table 7). A great influence of the wind on canopy storage capacity was established, therefore the events with high wind velocity (over $4 \mathrm{~m} / \mathrm{s}$ ) in the full-leaf period were removed from the analyses. The estimated values are consistent with the values generated in other deciduous stands. For the deciduous forest in Canada, Carlyle-Moses and Price (1999) estimated the $S$ value at $1.1 \mathrm{~mm}$, Dolman (1987) for oak forest in the Netherlands $0.3-0.8 \mathrm{~mm}$, and for the deciduous forest in the Netherlands Lankreijer et al. (1993) estimated $\mathrm{S}$ at $0.7 \mathrm{~mm}$.

The estimated trunk storage capacity $S_{t}$ was between 0.05 and 0.09 on the south plot and between 0.06 and 0.08 on the north plot (Table 7). The proportion of rainfall going to trunks $p_{t}$ was found to be $0.05-0.07$ on the south plot and 0.03-0.04 on the north plot (Table 7). When comparing the values on both plots, it can be established that on the south plot the proportion of the stemflow is constantly higher, which is in accordance with the measured data.

The estimated ratio of mean wet canopy evaporation rate $\bar{E}$ over average rainfall intensity $\bar{R}$ ranged from 0.18 (leaf-less period) to 0.46 (leafing-out period) for the south plot and from 0.20 to 0.44 for the north plot (Table 7$)$. These values $(\bar{E} / \bar{R})$ are in agreement with those found by other researchers and they typically range from $0.15 \mathrm{~mm} / \mathrm{h}$ (Loustau et al., 1992; Carlyle-Moses and Price, 1999) to $0.46 \mathrm{~mm} / \mathrm{h}$ (Pearce and Rowe, 1981; Carlyle-Moses and Price, 1999).

Table 7. Vegetation and meteorological parameter values for each vegetation period on the south and north plot, respectively.

\begin{tabular}{|c|c|c|c|c|}
\hline$=$ & Leaf-fall period & Leafless period & $\begin{array}{c}\text { Leafing-out } \\
\text { period }\end{array}$ & Full-leaf period \\
\hline \multicolumn{5}{|l|}{ South plot } \\
\hline $\mathrm{S}$ [mm] (Leyton) & 0.9 & 0.4 & 1.1 & 1.2 \\
\hline $\mathrm{p}$ (Jackson) & 0.44 & 0.57 & 0.18 & 0.06 \\
\hline $\mathrm{p}_{\mathrm{t}}[-]$ & 0.05 & 0.06 & 0.07 & 0.06 \\
\hline $\mathrm{S}_{\mathrm{t}}[\mathrm{mm}]$ & 0.05 & 0.06 & 0.09 & 0.08 \\
\hline $\bar{E} / \bar{R}$ & 0.206 & 0.181 & 0.457 & 0.271 \\
\hline \multicolumn{5}{|l|}{ North plot } \\
\hline $\mathrm{S}$ [mm] (Leyton) & 1.0 & 0.2 & 1.1 & 1.3 \\
\hline $\mathrm{p}$ (Jackson) & 0.48 & 0.83 & 0.34 & 0.20 \\
\hline $\mathrm{p}_{\mathrm{t}}[-]$ & 0.04 & 0.04 & 0.03 & 0.04 \\
\hline $\mathrm{S}_{\mathrm{t}}[\mathrm{mm}]$ & 0.08 & 0.06 & 0.06 & 0.07 \\
\hline $\bar{E} / \bar{R}$ & 0.217 & 0.200 & 0.440 & 0.200 \\
\hline
\end{tabular}

The mean values of aerodynamic resistance ( \pm standard error) obtained with the momentum method were $15.92( \pm 0.85) \mathrm{s} / \mathrm{m}$ and $12.33( \pm 0.66) \mathrm{s} / \mathrm{m}$ for the south and north plot, respectively. The smaller value for the north forest stand was the consequence of higher mean tree height on the north plot because of increased turbulence from the deeper roughness layer 
(Valente et al., 1997; Pypker et al., 2005). Estimated values correspond well to those reported for forests being around 10-15 s/m (Bruijnzeel, 2000). The lower aerodynamic resistance of the north stand accelerates faster evaporation, which might also be the reason that the difference in interception losses between both plots was smaller than expected.

The analytical Gash model of rainfall interception (Gash, 1979; Gash et al., 1995) was applied for the measuring period (5/10/2000-12/9/2001) for both plots. The model for the south plot yielded good results for the interception cumulative values (Fig. 9) with a root mean squared error (RMSE) of $13.42 \mathrm{~mm}$, i.e. average relative RMSE of $3.6 \%$. The highest cumulative difference between the estimated and modelled interception loss occurred at the end of the discussed period, when the modelled value $(430.95 \mathrm{~mm}$ or $32.7 \%$ of gross rainfall) exceeded the estimated value ( $374.09 \mathrm{~mm}$ or $28.4 \%$ of gross rainfall) on the basis of water balance by $15.2 \%$ (Fig. 9). On the other hand, RMSE of $16.67 \mathrm{~mm}$ was found for the throughfall cumulative values, i.e. average relative RMSE of $1.9 \%$. The value of modelled throughfall $T f$ ( $812.76 \mathrm{~mm}$ or $61.6 \%$ of gross rainfall) at the end of the period gave an underestimation of the measured values $(885.20 \mathrm{~mm}$ or $67.1 \%$ of gross rainfall) on the basis of water balance by $8.2 \%$.

The individual evaporation components were calculated according to the equations by Gash (1979) (Table 1). The highest total evaporation was provided by the evaporation from wet saturated canopies during storms, this being approximately two thirds of total evaporation. In second place was evaporation after storms, i.e. evaporation during the drying-up period (15$20 \%$ ), other proportions were less than $10 \%$.

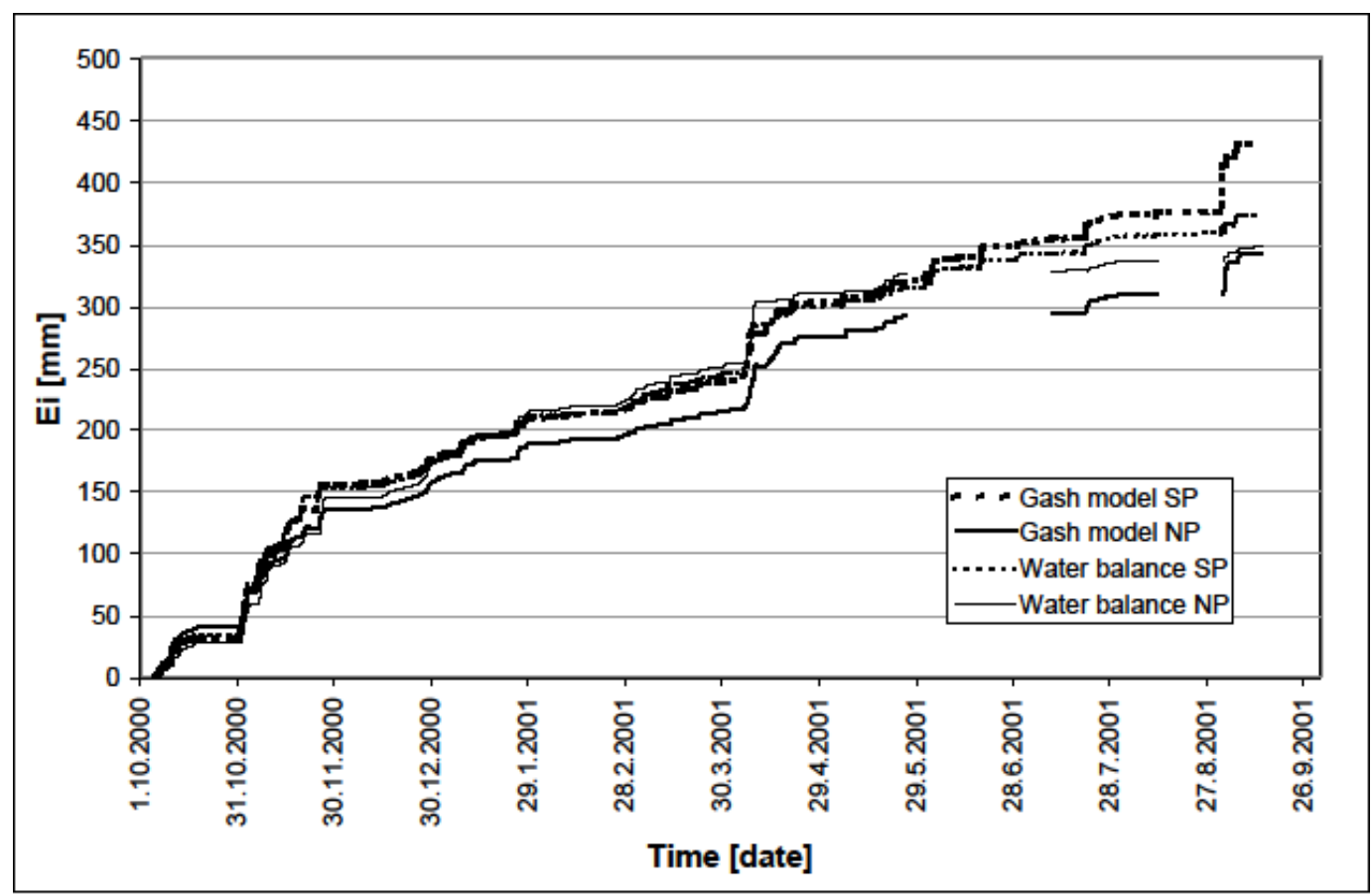

Fig. 9. Comparison of estimated and modelled interception losses for the south (SP) and north plot (NP), respectively.

Due to technical difficulties there were no measurements on the north plot in the month of June and for one day in August, thus the events from the period were left out of the model. The modelled value of interception loss on the north plot at the end of the period $(341.21 \mathrm{~mm}$ 
or $27.6 \%$ of gross rainfall) underestimated the estimated value $(346.47 \mathrm{~mm}$ or $28.1 \%$ of gross precipitation) on the basis of water balance by $1.5 \%$ (Fig. 9). RMSE value for the interception cumulative values was $17.35 \mathrm{~mm}$, i.e. average relative RMSE was $5.0 \%$. On the north plot the model for a particular period underestimated the estimated values of the interception loss by up to $17 \%$ and overestimated the $T f$ values by up to $7 \%$. The modelled values of $T f$ at the end of the period were $845 \mathrm{~mm}$ or $68.44 \%$ of gross precipitation and estimated $868.10 \mathrm{~mm}$ or $70.31 \%$ of gross precipitation. Predictions of the model resulted in a $R M S E$ of $16.23 \mathrm{~mm}$ for the cumulative throughfall values, i.e. in an average relative RMSE of $1.9 \%$.

The overall performance of the model was satisfying. If we considered the random error of 5 $\%$ in rainfall, throughfall and stemflow readings (Gash et al., 1980; Gash et al., 1995; Dykes, 1997 ), the quadratic sum of calculated errors gives a total error of $\pm 79.5 \mathrm{~mm}$ or $\pm 21.2 \%$ of the end estimated interception loss for the south plot and $\pm 75.5 \mathrm{~mm}$ or $\pm 21.8 \%$ for the north plot. The results of the modelling were within the limits of the standard error of the observed values. By way of comparison, Calder et al. (1986) reported of $25 \%$ error in the total measured interception, and Dykes (1997) even as much as $36 \%$. Sensitivity analysis has shown that the relative evaporation rate $\bar{E} / \bar{R}$ is to be considered as the most influential parameter, since a $10 \%$ change in the south plot leads to a $7 \%$ change in the modelled interception loss, while the same degree of change of the canopy storage capacity $S$ results in a change of modelled interception loss of only $1.4 \%$. An even smaller influence on the modelled interception loss has the proportion of gross precipitation that passes through the canopy without striking the canopy $p$. A $10 \%$ increase of the parameter reduced the end modelled value of interception loss by only $0.8 \%$. A similar sensitivity pattern was found by Gash and Morton (1978), Gash (1979), Loustau et al. (1992), Valente et al., 1997; Shellekens et al. (1999).

\section{Conclusions}

Differences in interception losses between deciduous forests on the north and south slopes in the Dragonja watershed were expected, since there are considerable differences in structure, density, and tree height, as well as in the composition. However, the measurements and analyses showed a lower difference of mean annual interception loss between both plots.

Throughfall depends on the canopy structure and the rainfall intensity and varies spatially. Therefore, throughfall was measured with fixed and roving gauges and regression analyses between both methods showed that roving gauges in the full-leaf season gave larger amounts of Tf. The average annual corrected $T f$ value was $67.1( \pm 9.6) \%$ and $71.5( \pm 11.6) \%$ of incoming rainfall for the south and north slopes, respectively. The highest $T f$ values in summer showed the large influence of rainfall intensity on throughfall and interception loss. Rainfall intensity is to be considered as the most influential factor on the throughfall.

Stemflow fraction of $4.5( \pm 0.8) \%$ and $2.9( \pm 0.6) \%$ for the south and north plot, respectively, showed the dependence of stemflow on tree density, tree height, DBH and roughness of the bark. Higher values on the south plot were the consequence of the higher 
tree density, lower trees, shorter branches, smaller $D B H$ and smoother bark of the trees on that plot. No clear seasonality was found.

The average annual interception losses amount to $28.4( \pm 4.1)$ and $25.4( \pm 4.0) \%$ of incoming rainfall for the south and north slopes, respectively. Both values are relatively high compared with other similar studies and do not differ essentially. Obviously, the vegetation on both plots adapted with its characteristics to a different solar exposure so that it functioned outwards in a similar way. For instance, higher tree height on the north plot caused lower aerodynamic resistance which caused faster evaporation. A comparison by seasons did not show any significant deviations, with the exception of summer, when the interception loss on the south plot was almost five-fold higher than on the northern side, which was the consequence of higher solar radiation on the south plot.

The leaf area index is one of the most important canopy structure characteristics. It was estimated by three methods, one direct and two indirect methods. Both indirect methods under-estimate the LAI values. The obtained mean maximum values of LAI by literfall method were 6.6 and 6.9 for the south and north plot, respectively. A smaller value on the south plot could be attributed to the growing conditions (less water availability).

Influence of air mass properties on interception was studied using wind speed and direction as well as air temperature and air humidity. A significant influence of the wind over the value of interception loss was proven. If the wind speed is over $4 \mathrm{~m} / \mathrm{s}$, the wind shakes the trees and thus reduces the storage capacity of the canopy and therewith the interception loss. Furthermore, with the classification decision tree model and data analysis it was established that the warm south-easterly wind (jugo) with a velocity higher than $4 \mathrm{~m} / \mathrm{s}$ considerably increased the interception loss in the foliated period (15 to $40 \%$ ). The increased evaporation and therefore higher interception losses in such events might have been the result of the local temperature increase, because the jugo is a warm wind with the characteristic rise in temperature and air humidity.

The results of the Gash analytical model indicate good agreement between the modelled and estimated interception losses. The model simulated both, throughfall values and interception losses, within the standard error of the observed values. All vegetation and meteorological parameters derived for the analytical model of interception loss were estimated separately for four vegetation periods during the study period and agreed well with those found by other researchers. Comparison of vegetation parameters between both plots gave logical explanations in accordance with the differences of characteristics of both forests and canopy structure.

More than a quarter of the precipitation above the forest of the Dragonja watershed evaporates back into the atmosphere during storm events or immediately after. However, these losses are relatively high, having in mind that the evaporated throughfall of deciduous forests is usually between 15 and $25 \%$ (Bruijnzeel, 2000). Such high loss of the deciduous forest of the Dragonja watershed is considerable, and could be a reason for the reduction of surface water runoff; however for further assumptions, measurements and analyses of transpiration and infiltration capacity of the soil should be done. 


\section{Acknowledgements}

We would like to thank Dr. L. A. Bruijnzeel and the Vrije Universiteit, Amsterdam, for the use of modern measuring equipment, the Slovenian National Committee for the IHP UNESCO for financial support, and the Environmental Agency of the Republic of Slovenia for data provision.

\section{REFERENCES}

Allen, R.G., Pereira, L.S., Raes, D., Smith, M., (1998). Crop evapotranspiration - Guidelines for computing crop water requirements. FAO Irrigation and drainage paper 56, FAO, Rome, 246 pp.

Atanasova, N., Kompare, B., 2002. The use of decision trees in the modelling of a wastewater treatment plant. Acta hydrotechnica, 20/33, 351-370.

Bonacci, O., 1991. The influence of errors in precipitation measurements on the accuracy of the evaporation measurements performed by a class A evaporation pan. Theoretical and Applied Climatology 43, 181-183.

Bosch, J., Hewlett, J.D., 1982. A review of catchment experiments to determine the effects of vegetation changes on water yield and evapotranspiration. Journal of Hydrology 55, 323.

Brilly, M., Globevnik, L., 2003. Sustainable Water Resources Management in the Dragonja Catchment, Slovenia. Water Resources Systems - Hydrological Risk, Management and Development. IAHS Publication 281, 334-340.

Bruijnzeel, L.A., 2000. Forest Hydrology. In Evans, J.S. (Editor): The Forestry Handbook, Volume 1. Blackwell, Oxford, 301-343 (Chapter 12).

Bruijnzeel, L.A., Wiersum, K.F., 1987. Rainfall interception by a young acacia auriculiformis (a. cunn) plantation forest in West Java, Indonesia: application of Gash's analytical model. Hydrological Processes 1, 309-319.

Calder, I.R., 1998. Water use by forests, limits and controls. Tree Physiol. 18, 625-631.

Calder, I.R., Wright, I.R., Murdiyaeso, D., 1986. A study of evapotranspiration from tropical rainforest - West Java. Journal of Hydrology 89, 13-31.

Carlyle-Moses, D.E., Price, A.G., 1999. An evaluation of the Gash interception model in a northern hardwood stand. Journal of Hydrology 214, 103-110.

Cescatti, A., 2007. Indirect estimates of canopy gap fraction based on the linear conversion of hemispherical photographs: Methodology and comparation with standard thresholding techniques. Agricultural and Forest Meteorology 143, 1-12.

Chang, M., 2003. Forest hydrology - an introduction to water and forests, CRC Press, $373 \mathrm{pp}$.

Chason, W.J., Baldocchi, D.D., Huston, M.A., 1991. A comparation of direct and indirect methods for estimating forest canopy leaf area. Agricultural and Forest Meteorology 57, $107-128$.

Chen, J.M., Govind, A., Sonnentag, O., Zhang, Y., Barr, A., Amiro, B., 2006. Leaf area index measurements at Fluxnet Canada sites, Agricultural and Forest Meteorology 140, 257 268. 
Chen, J.M., Rich, P.M., Gower, R.T., Norman, J.M., Plummer, S., 1997. Leaf area index of boreal forests: Theory, Tehniques and measurements. Journal of Geophysical research 102(D24), 29429-29443.

Dolman, A.J., 1987. Summer and winter rainfall interception in an oak forest, predictions with an analytical and a numerical simulation model. Journal of Hydrology 90, 1-9.

Dykes, A.P., 1997. Rainfall interception from a lowland tropical rainforest in Brunei. Journal of Hydrology 200, 260-279.

Eriksson, H., Eklundh, L., Hall, K., Lindroth, A., 2005. Estimating LAI in deciduous forest stands. Agricultural and Forest Meteorology 129, 27-37.

Gash, J.H.C., 1979. An analytical model of rainfall interception by forests. Quarterly Journal of the Royal Meteorological Society 105, 43-55.

Gash, J.H.C., Lloyd, C.R., Lachaud, G., 1995. Estimating sparse forest rainfall interception with an analytical model. Journal of Hydrology 170, 79-86.

Gash, J.H.C., Morton, A.J., 1978. An application of the Rutter model to the estimation of the interception loss from Thetford forest. Journal of Hydrology 38, 49-58.

Gash, J.H.C., Stewart, J.B., 1977. The evaporation from Thetford forest during 1975. Journal of Hydrology 35, 385-396.

Gash, J.H.C., Wright, L.R., Lloyd, C.R., 1980. Comparative estimates of interception loss from three coniferous forests in Great Britain. Journal of Hydrology 48, 89-105.

Globevnik, L., 2001. An integrated approach towards water management in catchments: an integrated analysis of time and spatial components of water regimes as the basis of modern procedures of modelling and planning of water management solutions, land use, and environmental protection: the Dragonja catchment. PhD Thesis, University of Ljubljana, 176 pp (in Slovenian).

Globevnik, L., Kaligarič, M., Sovinc, A., 2004. Forest cover progression, land-use and socioeconomic changes on the edge of the Mediterranean. In Mazzoleni, S., Pasquale, G., Mulligan, M., Martino, P., Rego, F. (editors): Recent dynamics of the Mediterranean vegetation and landscape, Wiley, 237-244 (Chapter 21).

Horton, R.E., 1919. Rainfall interception. Monthly Weather Rev. 47, 603-623.

Jackson, I.J., 1975. Relationships between rainfall parameters and interception by tropical forest. Journal of Hydrology 24, 215-238.

Jetten, V.G., 1996. Interception of tropical rain forest: performance of a canopy water balance model. Hydrological Processes 10, 671-685.

Jonckheere, I., Fleck, S., Nackaerts, K., Muys, B., Coppin, P., Weiss, M., Baret, F., 2004. Review of methods for in situ leaf area index determination. Part I. Theories, sensors and hemispherical photography. Agricultural and Forest Meteorology 121, 19-35.

Jones, J.A., 2000. Hydrologic processes and peak discharge response to forest removal, regrowth, and roads in 10 small experimental basins, western Cascades, Oregon. Water Resources Research 36, 2621-2642.

Keestra, S.D., van Huissteden, J., Vandenberghe, J., Van Dam, O., de Gier, J., Pleizier, I.D., 2005. Evolution of the morphology of the river Dragonja (SW Slovenia) due to land-use changes. Geomorphology 69, 191-207.

Krajcar, V., 2003. Statistical approach to wind induced currents in the Northern Adriatic. Geofizika 20, 93-103. 
Lankreijer, H.J.M., Hendriks, M.J., Klassen, W., 1993. A comparation of models simulating rainfall interception of forests. Agricultural and Forest Meteorology 64, 187-199.

Law, F., 1956. The effect of afforestation upon the yield of water catchment areas. Journal of the British Waterworks Associaton 38, 344-354.

Levy, P.E., Jarvis, P.G., 1999. Direct and indirect measurements of LAI in millet and fallow vegetation in HAPEX-Sahel. Agricultural and Forest Meteorology 97, 199-212.

Leyton, L., Reynolds, E.R.C., Thompson F.B., 1967. Rainfall interception in forest and moorland. In Sopper W.E., Lull, H.W. (Editors), International Symposium on Forest Hydrology, Pergamon Press, Oxford, 163-178.

Llorens, P., 1997. Rainfall interception by a Pinus sylvestris forest patch overgrown in a Mediterranean mountainous abandoned area. II. Assessment of the applicability of Gash's analytical model. Journal of Hydrology 199, 346-359.

Loustau, D., Berbiger, P., Granier, A., El Hadj Moussa, F., 1992. Interception loss, throughfall and stemflow in a maritime pine stand. I. Variability of throughfall and stemflow beneath the pine canopy. Journal of Hydrology 138, 449-467.

Macfarlane, C., Hoffman, M., Eamus, D., Kerp, N., Higginson, S., McMurtrie, R., Adams, M., 2007. Estimation of leaf area index in eucalypt forest using digital photography, Agricultural and Forest Meteorology 143, 176-188.

Miller, J.B., 1967. A formula for average foliage density, Australian Journal of Botany 15, 141-144.

Nobis, M., Hunziker, U., 2005. Automatic thresholding for hemispherical canopyphotographs based on edge detection. Agricultural and Forest Meteorology 128, 243250 .

Ogrin, D., 1995. Climate of the Istrian Peninsula. Library Annales 11, 381 pp (in Slovenian).

Pearce, A.J., Rowe, L.K., 1981. Rainfall interception in a multi-storied, evergreen mixed forest: estimates using Gash's analytical model. Journal of Hydrology 49, 341-353.

Petkovšek, G., Mikoš, M., 2004. Estimating the R factor from daily rainfall data in the subMediterranean climate of southwest Slovenia. Hydrological Sciences Journal 49(5), 869-877.

Putuhena, W.M., Cordery, I., 2000. Some hydrological effects of changing forest cover from eucalypts to Pinus radiata. Agricultural and Forest Meteorology 100, 59-72.

Pypker, T.G., Bond, B.J., Link, T.E., Marks, D., Unsworth, M.H., 2005. The importance of canopy structure in controlling the interception loss of rainfall: Examples from a young and an old-growth Douglas-fir forest. Agricultural and Forest Meteorology 130, 113129

Rowe, L.K., 1983. Rainfall interception by an evergreen beech forest, Nelson, New Zealand. Journal of Hydrology 66, 143-158.

Rutter, A.J., 1967. An analysis of evaporation from a stand of Scots pine. In: Sopper, W.E. and Lull, H.W. (Eds.). International Symposium on Forest Hydrology, Pergamon Press, Oxford, 403-416.

Schellekens, J., 2000. Hydrological processes in a humid tropical rain forest: a combined experimental and modelling approach. PhD Thesis Vrije University, Amsterdam, 158 pp. 
Schellekens, J., Scatena, F.N., Bruijnzeel, L.A., Wickel, A.J., 1999. Modelling rainfall interception by a lowland tropical rain forest in northeastern Puerto Rico. Journal of Hydrology 225, 168-184.

Stewart, J.B., 1977. Evaporation from the wet canopy of a pine forest. Water Resources Research 13, 915-921.

Stravs, L., Brilly, M., Sraj, M., 2007. Precipitation interception modelling using machine learning methods - The Dragonja river basin case study. In: Abrahart, R.J., See, L.M. and Solomatine, D.P. (Eds.): Hydroinformatics in practice: Computational intelligence and technological developments in water applications. Springer DE: Water Science and Technology Library. Invited contribution. (in publishing)

Swank, W.T., Swift, L.W., Douglas, J.E., 1988. Streamflow changes associated with forest cutting, species conversion and natural disturbances. Ecological Studies 66, 297-312.

Šraj, M., 2001. Watershed coding system of the Republic of Slovenia. Acta hydrotechnica, 19/30, 3-24.

Šraj, M., 2003a. Modeling and measuring of rainfall interception. Unpublished $\mathrm{PhD}$ Thesis, University of Ljubljana, $236 \mathrm{pp}$ (in Slovenian).

Šraj, M., 2003b. Estimating leaf area index of the deciduous forest in the Dragonja watershed. Part I: Methods and measuring. Acta hydrotechnica, 21/35, 105-127.

Šraj, M., 2004. Estimating leaf area index of the deciduous forest in the Dragonja watershed. Part 2: Results and discussion. Acta hydrotechnica, 22/36, 1-15.

Te Linde, A.H., 2001. Modelling rainfall interception by two deciduous forests of contrasting stature in the upper Dragonja catchment, southwestern Slovenia. Dragonja project working paper, Vrije University, Amsterdam, 42 pp.

Thom, A.S., 1975. Momentum, mass and heat exchange of plant communities. In: Monteith, J.L. (Ed.), Vegetation and the atmosphere, vol. 1, Academic Press, New York, 57-109.

Valente, F., David, J.S., Gash, J.H.C., 1997. Modelling interception loss for two sparce eucalypt and pine forests in central Portugal using reformulated Rutter and Gash analytical models. Journal of Hydrology 190, 141-162.

Van der Tol, C., Dolman, A.J., Waterloo, M.J., Raspor, K., 2007. Topography induced spatial variations in diurnal cycles of assimilation and latent heat of Mediterranean forest. Biogeosciences 4, 137-154.

Zinke, P.J., 1967. Forest interception studies in the United States. In: Sopper, W.E. and Lull, H.W. (Eds.). International Symposium on Forest Hydrology, Pergamon Press, Oxford, 137-160.

Zorn, M., 1975. Forest Vegetation Map of the Republic of Slovenia - Description of Woodland Vegetation. Forestry Planning Office, Ljubljana, $150 \mathrm{pp}$ (in Slovenian).

Waterloo, M.J., Bruijnzeel, L.A., Vugts, H.F., Rawaqa, T.T., 1999. Evaporation from Pinus caribaea plantations on former grassland soils under maritime tropical conditions. Water Resources Research 35, 2133-2144.

Witten, I.H., Frank, E., 2000. Data mining: Practical machine learning tools and tehniques with java implementations. Morgan Kaufmann Publishers, San Francisco, USA. 